BIS WORKING PAPERS

No 93 - October 2000

\title{
TRADING VOLUMES, VOLATILITY \\ AND SPREADS IN FOREIGN EXCHANGE MARKETS: \\ EVIDENCE FROM EMERGING MARKET COUNTRIES
}

by

Gabriele Galati

BANK FOR INTERNATIONAL SETTLEMENTS

Monetary and Economic Department

Basel, Switzerland 
BIS Working Papers are written by members of the Monetary and Economic Department of the Bank for International Settlements, and from time to time by other economists, and are published by the Bank. The papers are on subjects of topical interest and are technical in character. The views expressed in them are those of their authors and not necessarily the views of the BIS.

Copies of publications are available from:

Bank for International Settlements

Information, Press \& Library Services

CH-4002 Basel, Switzerland

Fax: $+4161 / 2809100$ and +4161/2808100

This publication is available on the BIS website (www.bis.org).

(C) Bank for International Settlements 2000.

All rights reserved. Brief excerpts may be reproduced or translated provided the source is stated. 
BIS WORKING PAPERS

No 93 - October 2000

\title{
TRADING VOLUMES, VOLATILITY
}

\section{AND SPREADS IN FOREIGN EXCHANGE MARKETS: EVIDENCE FROM EMERGING MARKET COUNTRIES}

by

Gabriele Galati*

\begin{abstract}
This paper provides empirical evidence on the relationship between trading volumes, volatility and bid-ask spreads in foreign exchange markets. It uses a new data set that includes daily data on trading volumes for the dollar exchange rates of seven currencies from emerging market countries. The sample period is 1 January 1998 to 30 June 1999 . The results are broadly consistent with the findings of the literature that used futures volumes as proxies for total foreign exchange trading. I find that in most cases unexpected trading volumes and volatility are positively correlated, suggesting that both are driven by the arrival of public information, as predicted by the mixture of distributions hypothesis. I also find that the correlation between trading volumes and volatility is positive during "normal" periods but turns negative when volatility increases sharply. Finally, the results suggest that volatility and spreads are positively correlated, as suggested by inventory cost models. However, contrary to the prediction of these models, I do not find evidence of a significant impact of unexpected trading volumes on spreads.
\end{abstract}

* I thank Javiera Aguilar, Claudio Borio, Alain Chaboud, Stefan Gerlach, Bob McCauley, Eli Remolona and Kostas Tsatsaronis for helpful comments and Florence Béranger and Anna Cobau for research assistance. 



\section{Contents}

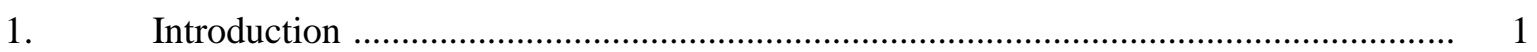

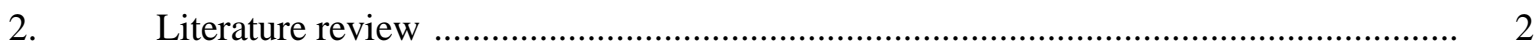

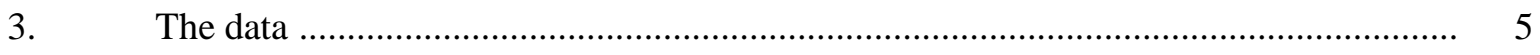

Exchange rates …........................................................................... 5

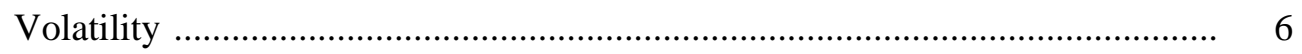

Trading volumes …............................................................................. 7

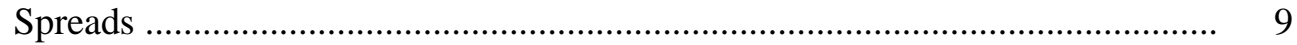

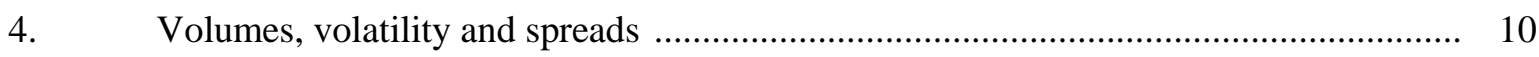

Trading volumes and volatility ........................................................... 10

Trading volumes and bid-ask spreads .................................................... 13

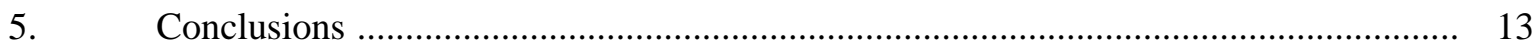

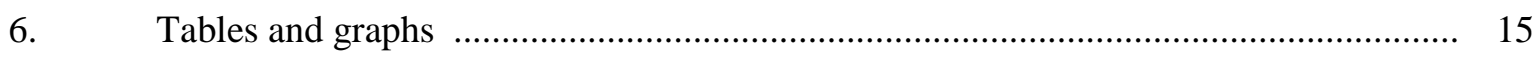

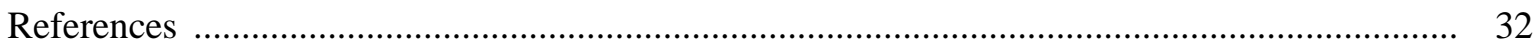





\section{Introduction}

This paper looks at the relationship between trading volumes, volatility and bid-ask spreads in foreign exchange markets. A number of studies on the microstructure of foreign exchange markets have looked at this issue from both a theoretical and an empirical point of view. From a policy perspective, the issue is important because of its implications for the analysis of market liquidity and its relationship with risk. Broadly speaking, a market can be considered to be liquid when large transactions can be executed with a small impact on prices (BIS (1999a)). In practice, however, no data are available that allow this definition of foreign exchange market liquidity to be measured directly. Instead, trading volumes or bid-ask spreads are frequently used as indirect measures. Volatility is often considered as a measure of risk.

This paper uses a new data set that for the first time matches daily data on trading volumes, volatility and spreads. The data set covers the dollar exchange rates of seven currencies from emerging market countries: the Colombian peso, the Mexican peso, the Brazilian real, the Indian rupee, the Indonesian rupiah, the Israeli shekel and the South African rand. The data cover the period from January 1998 to June 1999 and use total turnover in the local market. Since there is not much offshore trading in these currencies, local transaction volumes are fairly representative of total trading. In order to allow a comparison with foreign exchange markets in industrial countries and with the results from previous studies, the paper also looks at trading volumes from the Tokyo inter-dealer yen/dollar market. Finally, for the Mexican peso, data from a fairly active currency futures market on the Chicago Mercantile Exchange were also obtained. These data allow a direct comparison of volumes on foreign exchange and futures markets.

An important drawback of empirical studies in this area is that good data on foreign exchange trading volumes have so far not been available at high frequencies. The most comprehensive source of information on trading in foreign exchange markets, the triennial Central Bank Survey of Foreign Exchange and Derivatives Market Activity published by the BIS, for example, does not provide much information on the time series behaviour of trading volumes. Researchers have therefore looked at alternative data sources to find proxies for foreign exchange market turnover. By using actual spot market trading volumes, this paper is for the first time able to fill this important gap in the literature.

The empirical microstructure literature has typically found a positive correlation between volumes and volatility. A theoretical explanation of this finding is that volume and volatility are both driven by a common, unobservable factor, which is determined by the arrival of new information. This theory, also known as the mixture of distributions hypothesis, predicts that volatility will move together with unexpected trading volumes. A further common finding of the literature is that volume and spreads are 
positively correlated. The explanation provided by microstructure theory is that bid-ask spreads are determined inter alia by inventory costs, which widen when exchange rate volatility increases. Through the mixture of distributions hypothesis, this also establishes a positive link between unexpected volumes and spreads.

A main finding of this paper is that in most cases unexpected trading volumes and volatility are positively correlated, suggesting that they both react to the arrival of new information, as the mixture of distributions hypothesis predicts. This result is in line with the findings of the literature that relies on futures data. The markets for the Mexican peso and the real, however, provide important exceptions. In these two cases, the relationship between unexpected volumes and volatility is negative but not statistically significant. I provide evidence that this result is driven by the incidence of periods of turbulence and argue that the correlation between trading volumes and volatility may be positive during "normal" times but negative during periods of stress. I also find evidence of a positive correlation between volatility and spreads, as suggested by inventory cost models. However, the results do not show a significant impact of trading volumes on spreads.

The remainder of the paper is organised as follows. Section 2 reviews the main contributions to the literature on the relationship between trading volumes, volatility and spreads. Section 3 describes the data set that is used. In Section 4, I present some descriptive evidence on the relationship between volumes, volatility and spreads. I then use regression analysis to test whether the mixture of distributions hypothesis holds in foreign exchange markets. Section 5 concludes.

\section{Literature review}

There is extensive literature on the relationship between trading volumes and volatility in financial markets. Karpoff (1987) provides a good overview of the early literature. Most of the research has focused on stock markets and futures markets, for which data on volumes are more easily available. An important finding is that trading volume and price variability are positively correlated at different frequencies. The coefficient is highest for contemporaneous correlations. However, it does not always appear to be very sizeable. Evidence was found by Harris (1986) and Richardson et al (1987) for stock markets and by Cornell (1981) for commodity futures.

The empirical work on foreign exchange markets has suffered from the problem that good data on trading volumes are not easily available for foreign exchange markets since, unlike equity markets, they are for the most part decentralised. Different data sources were used to describe the time series behaviour of trading volumes. ${ }^{1}$ Many studies used data on futures contracts, which can be easily

1 A good overview of the characteristics of data sets used in the literature can be found in Lyons (2000). 
obtained, to proxy for interbank trading volumes. Studies that have found a positive correlation between volumes and volatility in these markets include Grammatikos and Saunders (1986), Batten and Bhar (1993) and Jorion (1996). An obvious drawback of these data sets is that trading in futures is very small compared to OTC volumes (Dumas (1996)). In the first quarter of 1998, for example, total turnover of currency futures traded on organised exchanges amounted to roughly $\$ 70$ billion (BIS (1998)), compared to total OTC turnover in spot, forward and swap markets of about $\$ 1,500$ billion (BIS (1999b)). While these two markets may still be closely linked through arbitrage (Lyons (2000)), little evidence is available on this link.

A widely used source of information on foreign exchange trading, the triennial Central Bank Survey of Foreign Exchange and Derivatives Market Activity published by the BIS, provides extensive cross sectional information but very little information on the time series behaviour of turnover. Hartmann (1998b) makes efficient use of these data by combining a large cross section of exchange rates taken from the BIS triennial survey with two time series observations into a panel, but still faces the problem of having limited time series information.

An alternative source of information is the Bank of Japan's data set on brokered transactions in the Tokyo yen/dollar market, which has been used by Wei (1994) and Hartmann (1999). A problem with these data is that they represent only a fraction (about one sixth) of total turnover in the Tokyo yen/dollar market and no more than $5 \%$ of the global yen/dollar market.

A number of papers have used the frequency of indicative quotes posted by Reuters on its FXFX page as a proxy for trading volumes. ${ }^{2}$ However, these quotes do not represent actual trades and it is not possible to infer from a quote for which volume it is given. Spreads that are quoted on the Reuters screen are generally far from actual traded spreads. ${ }^{3}$ Moreover, it is common for banks that act as data providers to programme an automated data input, eg by having a particular quote entered at regular time intervals. This is especially true for smaller banks that may have an interest in quoting prices in order to advertise their presence in a particular market segment. Finally, when an important event occurs, traders are likely to act and trade rather than entering data for Reuters. Hence, Reuters tick frequency may be low at times of high trading activity and high when markets are calm. The relationship between quote frequency and actual trading activity is therefore likely to be quite noisy.

A fruitful approach has been to look at high-frequency data on actual transactions in the OTC market. One such data set, used by Lyons (1995), covers all transactions that a foreign exchange dealer in New York entered with other dealers in one week in 1992. Goodhart et al (1996) analyse data on electronically brokered inter-dealer transactions that occurred on one day in 1993 . While these data

\footnotetext{
2 See for example, Goodhart and Figliuoli (1991) and Bollerslev and Domowitz (1993).

3 See also Hartmann (1998a).
} 
provide a wealth of information, including information on the direction of order flows, they necessarily cover only a limited segment of foreign exchange markets and span a relatively short time period.

Different theoretical explanations have been offered for the co-movement of trading volumes and volatility. Early work was based on models of "sequential information arrival" (Copeland (1976, 1977)), according to which information reaches one market participant at a time. As that agent reacts to the arrival of news, his demand curve will shift, thereby leading to a positive correlation between volume and volatility. An alternative explanation of the volume-volatility correlation is based on the "mixture of distributions hypothesis" first proposed by Clark (1973). According to this hypothesis, volume and volatility are both driven by a common, unobservable factor. This factor reflects the arrival of new public information and determines a positive correlation between unexpected turnover and unexpected volatility. Tauchen and Pitts (1983) show that volume and volatility can co-move for two reasons. First, as the number of traders grows, market prices become less volatile. Second, given the number of traders, an increase in volume reflects greater disagreement among traders and hence leads to higher volatility. This link is stronger when new information arrives at a faster rate. In a recent paper, Melvin and Yin (2000) investigated the relationship between the arrival of new public information, the quoting frequency and the volatility of dollar/yen and dollar/mark exchange rates. They analysed intra-day data taken from Reuters screens on indicative quotes and news headlines related to the United States, Germany or Japan for the period 1 December 1993 to 26 April 1995. They found that the amount of information arriving on a particular hour of a particular day of the week is positively related to the amount of quoting activity and exchange rate volatility.

Models that explain bid-ask spreads in terms of inventory costs establish a link between bid-ask spreads, volatility and trading volumes. One determinant of inventory costs is the cost of maintaining open positions, which is positively related to price risk. ${ }^{4}$ According to this view, exchange rate volatility increases price risk and thereby pushes up spreads. Supporting evidence is provided by Bessembinder (1994), Bollerslev and Melvin (1994) and Hartmann (1999), who found a positive correlation between spreads and expected volatility measured by GARCH forecasts.

A second determinant of inventory costs is trading activity. Trading volumes can have a different impact on spreads depending on whether they are expected or unexpected. Expected trading volumes should be negatively correlated with spreads to the extent that they reflect economies of scale and are associated with higher competition among market-makers (Cornell (1978)). By contrast, unexpected

4 The microstructure literature analyses two other types of costs: order processing costs (ie costs of providing liquidity services) and asymmetric information costs (Bessembinder (1994), Jorion (1996) Hartmann (1999), Lyons (2000)). Order processing costs are arguably small in foreign exchange markets (Jorion (1996)). Recent research (Lyons (2000)) stresses the importance of asymmetric information costs. 
trading volumes should have a positive impact on spreads to the extent that they reflect the arrival of news.

\section{The data}

This paper looks at the dollar exchange rates of seven currencies from emerging market countries: the Indonesian rupiah, the Indian rupee, the Mexican peso, the Brazilian real, the Colombian peso, the South African rand and the Israeli shekel. ${ }^{5}$ As a benchmark for comparison, it also looks at the brokered interbank dollar/yen market in Tokyo. The paper uses daily data over the sample period January 1998 to June $1999 .^{6}$ The important novelty of this paper is that it uses daily data on trading volumes, volatility and bid-ask spreads. This is the first time a data set with high-frequency data on trading volumes that are representative of a foreign exchange market has been used in the literature.

This section reviews the main characteristics of the variables investigated. It starts with a description of the exchange rates and their volatility. It then analyses in detail the data on trading volumes. Finally, it describes the behaviour of bid-ask spreads.

\section{Exchange rates}

According to the IMF classification, during this period these exchange rates either floated independently or were managed in some form (Table 1). Graph 1 and Table 2 provide information on their behaviour. As a benchmark for comparison, information on the yen/dollar rate is also shown. During the period under review, the exchange rates of these emerging market currencies generally depreciated against the dollar. The depreciation was particularly sharp following the Russian crisis in August 1998, except in the case of the real.

The real depreciated at a constant rate against the dollar in 1998. Following intense speculative pressures, the Brazilian authorities had to allow it to float freely on 15 January 1999 and it plunged from 1.1 to almost 2.2 reais to the dollar. The real recovered somewhat in the following months, and in June 1998 traded around a level of 1.75 to the dollar. The Mexican peso depreciated for most of 1998 and early 1999. However, it moved within a much smaller range than the real. The Mexican peso's weakness was exacerbated following the Russian crisis in August 1998, when it depreciated by around $20 \%$ against the dollar. It also fell, albeit not as much, in January 1999, during the period of speculative attacks on the real. The Colombian peso's downward trend and fluctuation range against the US dollar were similar to those of the Mexican peso. In August 1998, pressure on the Colombian

\footnotetext{
5 Dollar exchange rates are defined in terms of units of domestic currency per dollar.

6 The choice of sample period is dictated by the availability of data on trading volumes.
} 
currency stepped up, inducing the authorities to widen the intervention band by $9 \%$, effectively devaluing the currency. The peso came under renewed pressure in January and March 1999. In June 1999, it depreciated by about $20 \%$.

The Indian rupee's behaviour was characterised by periods of stability followed by marked downward movements, notably in May 1998. The Indonesian rupiah fell sharply in January and July 1998. Its volatility declined in 1999 but still remained very high.

The South African rand depreciated markedly against the dollar around the time of the Russian crisis in summer 1998. In the second half of the year it recouped part of its losses but in 1999 trended down again. In 1998, the shekel followed a slightly depreciating trend against the dollar. It fell by $20 \%$ in October 1998 but stabilised in the following weeks.

Unlike the exchange rates of the seven emerging market currencies, the movements of the dollar/yen rate were much smoother over most of the sample period. However, in October 1998 the dollar fell sharply and lost about $20 \%$ against the yen in a few days.

Graph 3 and Table 3 report information on the percentage exchange rate changes for the seven currencies. For the real, statistics are also presented separately for the period January-June 1999, during which it floated. Between January 1998 and June 1999, the average daily percentage change of most of the currencies was significantly positive, with the exception of the Colombian peso and the rupee. Their standard deviation ranged between 0.29 for the rupee and 4.24 for the rupiah. Over the same period, the standard deviation of the yen/dollar rate was close to 1. Most exchange rate changes exhibited positive skewness consistently with their downward trend, and leptokurtosis. Table 4 suggests that the exchange rate changes exhibited very little persistence.

\section{Volatility}

Graph 1 shows the historical volatility of the seven exchange rates computed over moving windows of one month. Summary statistics are reported in Table 5. In terms of their volatility, the seven exchange rates can be divided into two groups. The real and the rupiah experienced sharp volatility spikes and were characterised by very high average volatility. By contrast, the historical volatilities of the rupee, the shekel and the Colombian peso remained quite low, averaging less than $8 \%$. The rand's volatility was relatively low on average, but it spiked at about $50 \%$.

Table 5 shows that the volatility of the yen/dollar exchange rate during the same period averaged $15 \%$. This is much less than the volatility of the real or the rupiah vis-à-vis the dollar, but more than the volatility of the other five exchange rates in this data set.

A finding that is common for exchange rates and other asset prices is the existence of volatility clustering, ie the fact that periods of persistent turbulence are followed by periods of relative calm. In 
the finance literature, this phenomenon has typically been described by some ARCH-type models. Tests for ARCH-type effects presented in Table 6 suggest that the exchange rates under investigation - with the possible exception of the Colombian peso - exhibit some ARCH-type behaviour. This behaviour seems to be fairly well captured by a $\operatorname{GARCH}(1,1)$ model.

Finally, Table 7 presents evidence that, for half of the exchange rates, volatility follows a time trend. The trend is positive for the Colombian peso and the real and negative for the rupee and the rupiah. There is no evidence of weekend effects.

\section{Trading volumes}

A large body of literature has documented the behaviour of trading volumes in stock and bond markets. By contrast, there is relatively little work on foreign exchange markets, because of the difficulty of obtaining data with a sufficiently high-frequency in this decentralised market. This paper is the first that uses such data. I use daily data on local turnover on seven exchange rates from emerging market countries. ${ }^{7}$ The sample period is January 1998 to June 1999, except for the rupiah, for which data are available only from 1 January to 30 June 1999. Since there is not much offshore trading in these currencies, local transaction volumes are fairly representative of total trading. ${ }^{8}$ As a benchmark, I also included trading volumes from the Tokyo interbank market, which were used in previous studies. The time series of the trading volumes are shown in Graph 1 and summary statistics are reported in Table 8.

A comparison with data from the 1998 triennial survey suggests that taken together, trading in the seven currency pairs accounts for roughly $1-2 \%$ of total foreign exchange market turnover. The individual markets are characterised by very different levels of activity. The most active markets were those for the Mexican peso, the real and the rand. To get an idea of the size of these markets, trading of dollars against one of these currencies averaged about one third of local trading of Canadian or Australian dollars against the US dollar in April 1998. Taking the yen/dollar market as a benchmark, these markets are slightly smaller than the interbank market in Tokyo. The market for the rupee also appeared to be quite active ( $\$ 3.5$ billion a day), much more than that for the Indonesian rupiah (\$1 billion per day), which in 1995 and 1996 was the most active foreign exchange market in emerging market countries, with an average daily turnover of more than $\$ 8$ billion (BIS (1997)). Transaction volumes for the Colombian peso and the shekel, on the other hand, are relatively small.

7 The sources for these data are national central banks.

8 Until 1997, there was a fairly active rupiah/dollar market in Singapore. However, most of this activity disappeared following the Asian crisis. 
Graph 1 reveals some interesting facts about the behaviour of trading volumes. First, it shows that foreign exchange turnover involving the real, the Colombian and Mexican pesos and the rand fell substantially around the end of August 1998, when the Russian crisis sparked a global reduction of liquidity in financial markets. The decline in trading volumes was particularly sharp in Mexico and Brazil.

Second, while trading volumes behaved differently around periods of speculative pressures, they always fell substantially once the pressures abated. ${ }^{9}$ This fact can be illustrated with the examples of the real and the Colombian peso. At the time of the speculative attack on the real in January 1999, trading volumes for the real rose for a short time and became more volatile. After Brazilian authorities decided to float the real on 12 January 1999, trading of reais against dollars remained very volatile for several weeks, before shrinking substantially around mid-February. In the following months, turnover built up again steadily but remained below levels observed before the crisis.

The Colombian peso was subject to two rounds of pressure in 1999. When pressure first mounted in March, there appears not to have been a significant increase in foreign exchange turnover. Subsequently, daily turnover dried up from about $\$ 200$ million to less than $\$ 50$ million. At the time of the second attack on the peso in June 1999, turnover increased sharply to $\$ 150$ million or more. Since our sample period ends on 30 June 1999, it is not possible to verify how trading volumes behaved after the second attack.

Regressions of trading volumes on a constant, a linear time trend and a dummy variable capturing weekend effects show a negative trend for trading in the Colombian and Mexican pesos, the real (until January 1999) and the rand. By contrast, there is evidence that turnover in the rupiah followed a positive time trend. The volume of yen/dollar transactions brokered in Tokyo did not exhibit any time trend. Graph 2, which plots turnover in selected emerging markets over a longer horizon (and at a lower frequency), puts these findings in perspective. It suggests that trading in emerging market currencies rose in the mid-1990s but in most cases fell after the Asian crisis and again at the time of the global reduction of liquidity in financial markets in 1998. Finally, Table 7 also shows that weekend effects appear to be present in about half of the cases.

For the Colombian peso, data on the transaction frequency are also available. It is sometimes argued that the combination of these data and trading volumes provides a good indicator on market liquidity. Table 8 suggests that for the Colombian peso/dollar exchange rate the behaviour and statistical properties of turnover and transaction frequency are very similar.

9 This is true even when volumes are measured at constant exchange rates. 
Futures contracts for three exchange rates: Mexican peso/dollar, real/dollar and rand/dollar are traded on the Chicago Mercantile Exchange. ${ }^{10}$ Table 9 provides summary statistics for these series. Trading is most active for the Mexican peso/dollar contracts, but in any case much less - no more than 3\% - than OTC turnover. Graph 3 shows that on many days there is actually no exchange-based trading at all involving the rand or the real. Exchange-traded and OTC volumes appear not to have co-moved closely in 1998 and 1999. The correlation coefficient of daily percentage changes is less than $1 \%$ for the Mexican peso, $4 \%$ for the rand and $18 \%$ for the real.

Table 10 presents some summary statistics on the changes of daily trading volumes. On average, trading volumes for the Colombian peso, the rand, the real and the rupiah appear to be most stable. The statistic for the rupiah is particularly noteworthy and indicative of the low variability of turnover associated with the low activity after the Asian crisis. For the Colombian peso, the statistics for changes in turnover and changes in transaction frequency appear to be very similar. The Mexican peso and the shekel exhibit the highest average variability of trading volumes.

Finally, Table 11 reports evidence on the presence of linear time trends in the time series for the trading volumes. It also shows that day-of-the-week effects characterise only a few of these series.

\section{Spreads}

Table 12 reports summary statistics on bid-ask spreads, expressed as a fraction of the exchange rate. The source for these data is DRI. As a benchmark for comparison, it also provides information on the spreads on brokered yen/dollar transactions in Tokyo. A caveat about these data is that they refer to indicative quotes rather than to actual transactions. Spreads on actual trades may be much smaller (and possibly less volatile), especially when one looks at electronically brokered transactions. ${ }^{11}$ Subject to this caveat, Table 12 shows that spreads on exchange rates from emerging market countries are much higher and much more volatile than spreads on the yen/dollar exchange rate. Their average in 1998 and 1999 ranged from $0.12 \%$ of the exchange rate for the Mexican peso to more than $2 \%$ for the rupiah, compared to spreads of around $0.05 \%$ for the yen/dollar market. Table 13 provides some additional information on the variations of the bid-ask spreads.

10 There is also active trading in real/dollar futures contracts on the BM\&F in São Paolo and the rand in London.

11 See Lyons (1995), Hartmann (1999) and Cheung and Chinn (1999). Most yen/dollar spot transactions between banks are nowadays conducted through electronic brokers and have spreads of about two to three hundredths of a US cent. 


\section{Volumes, volatility and spreads}

\section{Trading volumes and volatility}

In terms of the contemporaneous correlation between daily foreign exchange turnover and exchange rate volatility, Table 14 shows positive coefficients for five out of seven emerging market exchange rates (the dollar exchange rates of the Colombian peso, the rand, the rupee, the rupiah and the shekel). The correlation is also positive for the yen/dollar rate traded in the Tokyo interbank market. This holds irrespective of whether exchange rate volatility is measured by absolute values of percentage changes, squared returns or the standard deviation of daily returns computed over rolling windows of one month. By contrast, I find a negative correlation for the real and the Mexican peso.

Regressions of volatility on a constant, a time trend, a day-of-the-week dummy and trading volumes give positive and statistically significant coefficients for all currencies except the real and the Mexican peso (Table 16). For the Colombian peso, a regression of volatility on the number of deals per day also gives a positive and statistically significant coefficient. With the exception of the real and the Mexican peso, these results are consistent with the positive correlation of volatility and volume found for currency futures (Grammatikos and Saunders (1986), Jorion (1996)).

Table 15 shows that for the Mexican peso, exchange-traded data yield a positive correlation between volatility and volumes. This result suggests that exchange-traded data may not always be an appropriate proxy for total interbank trading.

The positive correlation between volumes and volatility found for most of the exchange rates is unlikely to be a reflection of changes in the number of traders active in these markets. These changes appear rather to have occurred in the mid-1990s, when banks increasingly moved into emerging markets, and after the Asian crisis, when the sharp fall in turnover was accompanied by a significant decline in the number of traders. A more plausible explanation for the positive correlation between turnover and volatility is that both variables are driven by the arrival of new information.

To test this hypothesis, I split volatility and trading volumes into expected and unexpected components. I use estimates from a $\operatorname{GARCH}(1,1)$ model to describe expected volatility. This model appears to fit the time series well. ${ }^{12}$ Ideally, volatility implied in option prices could be used, since there is evidence that it outperforms GARCH models in providing forecasts of future volatility. ${ }^{13}$ However, option contracts for currencies of emerging market countries are not very liquid, particularly after the Asian crisis. The GARCH(1,1) model can be written as:

12 Following a practice common in the literature, the GARCH model is fitted on the entire time series, thus yielding insample forecasts. 
(1) $R_{t}=\mu+r_{t}, \quad r \sim N\left(0, h_{t}\right), \quad h_{t}=\alpha_{0}+\alpha_{1} r_{t-1}^{2}+\beta h_{t-1}$

where $R_{t}$ is the return, $\mu$ its mean and $h_{t}$ its conditional variance at time $t$.

In order to measure expected trading volumes, I used the Box-Jenkins analysis to select a parsimonious time series representation for the volume series, which are taken in logs. Time series models were fitted on the levels of trading volumes since Augmented Dickey-Fuller tests suggest that they are stationary. AR models, in most cases of first order, seemed appropriate to represent the turnover series. These models allow trading volumes to be split into an expected and an unexpected component.

The estimated regression equation takes the following form:

(2) $R_{t+1}^{2}=\alpha+\beta_{2} E_{t}(v)+\beta_{3}\left[v_{t+1}-E(v)\right]+\beta_{4} t+\beta_{5} w_{t}+\varepsilon_{t+1}$

where total volatility $R_{t+1}^{2}$ is defined as squared returns, and log volumes are decomposed into an expected component $E_{t}(v)$ and an unexpected component $\left[v_{t+1}-E_{t}(v)\right]$ by using a fitted AR series and its residuals. A linear time trend and a dummy capturing weekend effects are also included.

Equation (2) is then augmented with an expected volatility term $h_{t+1}$, which represents the one-stepahead conditional return variance from a $\operatorname{GARCH}(1,1)$ specification:

(3) $R_{t+1}^{2}=\alpha+\beta_{1} h_{t+1}+\beta_{2} E_{t}(v)+\beta_{3}\left[v_{t+1}-E(v)\right]+\beta_{4} t+\beta_{5} w_{t}+\varepsilon_{t+1}$

Table 17 reports the regression results for equation (3). The coefficient on unexpected turnover is positive and statistically significant at $1 \%$ or $5 \%$ in all the regressions for exchange rates from emerging market countries, except those for the Mexican peso and the real. For these two currencies, the coefficients are negative but not statistically significant. A positive, significant coefficient is also found for the yen/dollar rate traded in Tokyo. Except for the Mexican peso and the real, the results support the idea that information flow drives volatility and volumes, as implied by the mixture of distributions hypothesis. This result is consistent with the conclusion of the literature that used data on currency futures (Jorion (1996)). These results are independent of market size: they hold both for the smallest market (Colombian peso/dollar) and for the biggest market (rand/dollar) in emerging market

13 Jorion (1996). 
countries, as well as for the even bigger yen/dollar interbank market in Tokyo. This is consistent with the finding presented in Batten and Bhar (1993) for futures markets. In contrast to Jorion's results, however, expected volumes also have a positive, significant effect on volatility in three cases (the rupee, the shekel and the yen).

Table 18 shows the results for regressions that also include expected volatility, measured by the GARCH forecast, among the explanatory variables. The coefficient on unexpected turnover remains positive and statistically significant in most cases. This is in line with the results presented in Jorion (1996). Again, the coefficient on unexpected trading volume is negative but not statistically significant for the Mexican peso and the real. In these cases only, the GARCH volatility forecast is also significant.

Overall, the results support the idea that the arrival of new public information drives the positive correlation between volumes and volatility, as postulated by the mixture of distributions hypothesis. Favourable evidence is found for four out of six exchange rates from emerging market countries and for the Tokyo interbank yen/dollar market. These findings appear to be independent of market size. By contrast, the mixture of distributions hypothesis appears not to hold for the Mexican peso/dollar and real/dollar markets.

Since most emerging market currencies in the data set went through some periods of turbulence, it is natural to test whether the correlation between volatility and volume is different in "normal" and "stressful" times. The same argument may also hold for the dollar/yen rate, whose drastic change in October 1998 was unprecedented by historical standards.

For each exchange rate, Graph 4 plots the coefficients of regressions of changes in volatility on a constant and (the logarithm of) trading volumes estimated over rolling windows of three months. The shaded areas indicate periods of turmoil. The charts suggest that the relationship between volatility and trading volumes is indeed different in stressful and tranquil times. In the case of the real, the Mexican peso and the rand, this relationship is strongly negative during periods of turbulence. This suggests that the negative coefficient on trading volumes found in Tables $16-18$ is driven by the incidence of periods of stress.

One interpretation of this result is that the correlation between trading volumes and volatility is positive during "normal" times, ie when volatility is relatively low. When volatility reaches very high levels, this may induce traders to withdraw from the markets thereby leading to a negative correlation. The mixture of distributions hypothesis may then hold in "normal" market conditions but be violated during periods of market turmoil. Taking this argument one step further, one might posit that a positive correlation between volume and volatility is an indication of liquid markets and a negative correlation is a symptom of inadequate liquidity. 


\section{Trading volumes and bid-ask spreads}

Graph 1 highlights that in foreign exchange markets in emerging market countries, bid-ask spreads spiked during times in which volatility sharply increased and turnover fell. While spreads tended to narrow shortly after these episodes, in some cases they remained wide for some time. Table 14 shows that in foreign exchange markets in emerging market countries, spreads and volatility are positively correlated. In most cases spreads and trading volumes are negatively correlated, a result that contrasts with findings of the early literature. ${ }^{14}$ By contrast, the behaviour of spreads appears totally unrelated to changes in volumes and volatility in the Tokyo yen/dollar interbank market, as indicated by correlation coefficients close to zero.

To test these assertions, I regressed bid-ask spreads on the GARCH variance forecasts and measures of expected and unexpected trading volumes:

(4) $S_{t}=\alpha+\beta_{1} h_{t+1}+\beta_{2} E_{t-1}(v)+\beta_{3}\left[v_{t}-E_{t-1(v)}\right]+\beta_{4} w_{t}+\varepsilon_{t}$

The results are presented in Table 19. Consistent with the findings of the literature, the coefficient on the GARCH variance forecast is positive and statistically significant, suggesting that volatility influences bid-ask spreads through its effect on inventory costs. However, in contrast to the predictions of the theory, I do not find positive and significant coefficients on unexpected volumes. The coefficients on expected volumes are also not statistically significant. One explanation is that the sample period may be too short to allow for changes in these foreign exchange markets that lead to more efficient trade processing and higher competition among market-makers.

\section{Conclusions}

This paper has tried to provide a contribution to the literature on the microstructure of foreign exchange markets by investigating the empirical relationship between trading volumes, volatility and bid-ask spreads. Until now, most of the research in this area has relied on data on futures markets, since good data on turnover in foreign exchange markets were not easily available. One important critique of this approach is that volumes in futures markets are not representative of total foreign exchange market activity. This paper uses a new data set that includes daily data on trading volumes for the dollar exchange rates of seven currencies from emerging market countries: the Indonesian rupiah, the Indian rupee, the Mexican peso, the Brazilian real, the Colombian peso, the South African rand and the Israeli shekel. To allow a comparison with other studies, it also looks at trading volumes

14 See eg Glassman (1987). 
from the Tokyo inter-dealer yen/dollar market. The data set covers the sample period 1 January 1998 to 30 June 1999.

An important result is that on average unexpected trading volumes and volatility are positively correlated, suggesting that they both respond to the arrival of new information, as the mixture of distributions hypothesis predicts. This is consistent with the findings of the literature that relies on futures data. It suggests that the observation that futures markets are not representative is not “damaging” (Dumas (1996)).

The markets for the Mexican peso and the real, however, provide important exceptions. In these two cases, the relationship between unexpected volumes and volatility is negative but not statistically significant. Moreover, for the Mexican peso data from foreign exchange markets and futures markets yield opposite results, as unexpected futures volumes and volatility are positively correlated.

Evidence from rolling regressions suggests that for the real, the Mexican peso and the rand, the relationship between volumes and volatility is strongly negative during periods of turbulence. This indicates that the negative average coefficient on trading volumes is influenced by the incidence of periods of stress. One possible interpretation is that the correlation between trading volumes and volatility is positive during "normal" times but turns negative when volatility increases sharply, implying that the mixture of distributions hypothesis holds under "normal" market conditions but not during periods of stress.

I also find evidence of a positive correlation between volatility and spreads, as suggested by inventory cost models. This result is also consistent with the findings of the literature. Finally, in contrast to previous studies and to the mixture of distributions hypothesis, I do not find evidence of a significant impact of unexpected trading volumes on spreads. 


\section{Tables and graphs}

Table 1

Exchange rate regimes, 1998-99

\begin{tabular}{|l|l|}
\hline Currency & Exchange rate regime \\
\hline $\begin{array}{l}\text { Colombian peso } \\
\text { Mexican peso }\end{array}$ & $\begin{array}{l}\text { Managed floating within an intervention band } \\
\text { Rand }\end{array}$ \\
Real & $\begin{array}{l}\text { Independent float } \\
\text { Managed floating within an adjustable band against the US } \\
\text { dollar (mid-1995 to January 1999) }\end{array}$ \\
Rupee & $\begin{array}{l}\text { Independent float } \\
\text { Rupiah }\end{array}$ \\
Shekel & $\begin{array}{l}\text { Mree float (since the crisis in July 1997) } \\
\text { margins of fluctuation of +/- 15\%. }\end{array}$ \\
\hline 1 & The shekel has been fully convertible since May 1998. \\
Source: IMF Exchange Rate Arrangements and Restrictions, 1999. \\
\hline
\end{tabular}

Table 2

Summary statistics for exchange rate levels

\begin{tabular}{|c|c|c|c|c|}
\hline & Mean & Std dev & Min & Max \\
\hline Colombian peso & 1486.19 & 116.28 & 1305.83 & 1752.18 \\
\hline Mexican peso & 9.33 & 0.66 & 8.03 & 10.65 \\
\hline Rand & 5.73 & 0.51 & 4.88 & 6.62 \\
\hline Real & 1.36 & 0.30 & 1.12 & 2.19 \\
\hline Rupee & 41.75 & 1.41 & 38.3 & 43.52 \\
\hline Rupiah & 9614.66 & 2193.46 & 6000 & 16745 \\
\hline Shekel & 3.89 & 0.24 & 3.55 & 4.37 \\
\hline Memo item: & & & & \\
\hline Yen/dollar & 126.80 & 9.38 & 108.80 & 147.25 \\
\hline
\end{tabular}


Table 3

Summary statistics for percentage changes of exchange rates

\begin{tabular}{|c|c|c|c|c|c|c|c|}
\hline & Mean & Std dev & $\begin{array}{l}\text { Test mean } \\
=0\end{array}$ & Skewness & Kurtosis & Min & Max \\
\hline Colombian peso & 0.09 & 0.59 & $\begin{array}{c}2.77 \\
(0.01)\end{array}$ & $\begin{array}{l}2.42 \\
(0)\end{array}$ & $\begin{array}{l}21.34 \\
(0)\end{array}$ & -1.9 & 5.55 \\
\hline Mexican peso & 0.04 & 0.76 & $\begin{array}{c}1.07 \\
(0.28)\end{array}$ & $\begin{array}{l}1.1 \\
(0)\end{array}$ & $\begin{array}{l}6.15 \\
(0)\end{array}$ & -2.94 & 4.49 \\
\hline Rand & 0.06 & 1.05 & $\begin{array}{c}1.14 \\
(0.25)\end{array}$ & $\begin{array}{l}-1.33 \\
(0)\end{array}$ & $\begin{array}{l}17.14 \\
(0)\end{array}$ & -8.88 & 4.58 \\
\hline Real & 0.13 & 1.4 & $\begin{array}{c}1.78 \\
(0.08)\end{array}$ & $\begin{array}{l}1.39 \\
(0)\end{array}$ & $\begin{array}{l}28.15 \\
(0)\end{array}$ & -10.77 & 11.41 \\
\hline $\begin{array}{l}\text { Real } \\
(1.1-1.7 .1999)\end{array}$ & 0.32 & 2.4 & $\begin{array}{c}1.49 \\
(0.1)\end{array}$ & 0.58 & 7.59 & -10.77 & 11.41 \\
\hline Rupee & 0.03 & 0.29 & $\begin{array}{l}1.81 \\
(0.07)\end{array}$ & $\begin{array}{l}-0.24 \\
(0)\end{array}$ & $\begin{array}{l}20.3 \\
(0)\end{array}$ & -2.13 & 2.01 \\
\hline Rupiah & 0.14 & 4.24 & $\begin{array}{c}0.67 \\
(0.05)\end{array}$ & $\begin{array}{c}1.05 \\
(0.06)\end{array}$ & $\begin{array}{l}7.84 \\
(0)\end{array}$ & -18.47 & 22.6 \\
\hline Shekel & 0.04 & 0.5 & $\begin{array}{l}1.5 \\
(0.14)\end{array}$ & $\begin{array}{l}1.08 \\
(0)\end{array}$ & $\begin{array}{l}7.4 \\
(0)\end{array}$ & -2.25 & 2.87 \\
\hline $\begin{array}{l}\text { Memo item: } \\
\text { Yen/dollar }\end{array}$ & -0.02 & 1.02 & $\begin{array}{c}-0.29 \\
(0.8)\end{array}$ & -1.00 & 5.57 & -6.6 & 3.3 \\
\hline
\end{tabular}


Table 4

Sample autocorrelation coefficients

\begin{tabular}{|c|c|c|c|c|c|c|}
\hline & 1 & 2 & 5 & 10 & 20 & 60 \\
\hline \multicolumn{7}{|l|}{ Colombian peso } \\
\hline exchange rate & 0.18 & 0.02 & -0.04 & 0.04 & -0.01 & -0.05 \\
\hline volume & -0.25 & -0.06 & -0.1 & 0.0 & 0.03 & 0.08 \\
\hline bid-ask spread & na & na & na & na & na & na \\
\hline number of deals & -0.24 & -0.02 & 0.03 & 0.0 & 0.05 & 0.06 \\
\hline \multicolumn{7}{|l|}{ Mexican peso } \\
\hline exchange rate & -0.03 & 0.02 & 0.02 & 0.09 & 0.06 & 0 \\
\hline volume & -0.11 & -0.03 & 0.01 & 0.01 & -0.04 & -0.01 \\
\hline bid-ask spread & -0.21 & -0.02 & 0.01 & 0.02 & -0.02 & -0.1 \\
\hline \multicolumn{7}{|l|}{ Rand } \\
\hline exchange rate & -0.003 & -0.04 & 0.21 & 0.09 & -0.08 & 0.009 \\
\hline volume & -0.18 & -0.24 & 0.13 & 0.15 & 0.09 & 0.1 \\
\hline bid-ask spread & -0.03 & -0.004 & -0.01 & 0.05 & -0.01 & -0.005 \\
\hline \multicolumn{7}{|l|}{ Real } \\
\hline exchange rate & 0.15 & 0.16 & -0.11 & 0.11 & -0.01 & -0.03 \\
\hline volume & -0.18 & 0.01 & -0.09 & 0.11 & 0.23 & 0.04 \\
\hline bid-ask spread & -0.08 & 0.39 & -0.05 & 0.005 & -0.02 & -0.02 \\
\hline \multicolumn{7}{|l|}{ Rupee } \\
\hline exchange rate & 0.03 & 0.00 & -0.02 & 0.023 & 0.01 & -0.07 \\
\hline volume & -0.00 & -0.00 & -0.00 & -0.00 & -0.00 & -0.00 \\
\hline bid-ask spread & -0.15 & 0.20 & 0.05 & 0.03 & -0.02 & -0.02 \\
\hline \multicolumn{7}{|l|}{ Rupiah } \\
\hline exchange rate & 0.16 & 0.04 & 0 & 0.06 & 0.04 & 0.01 \\
\hline volume & -0.4 & 0.12 & 0.09 & -0.15 & 0.04 & -0.01 \\
\hline bid-ask spread & -0.01 & -0.004 & -0.004 & -0.005 & -0.004 & -0.002 \\
\hline \multicolumn{7}{|l|}{ Shekel } \\
\hline exchange rate & 0.12 & 0.2 & -0.02 & 0.13 & -0.05 & 0.03 \\
\hline volume & -0.15 & -0.01 & 0.22 & 0.08 & 0.02 & 0.18 \\
\hline bid-ask spread & -0.38 & 0 & -0.08 & 0.09 & -0.04 & 0.04 \\
\hline \multicolumn{7}{|l|}{$\begin{array}{l}\text { Memo item: } \\
\text { Yen/dollar }\end{array}$} \\
\hline exchange rate & 0.14 & 0.005 & -0.02 & 0.03 & 0 & 0.05 \\
\hline volume & -0.29 & -0.06 & 0.21 & 0.15 & 0.06 & 0.02 \\
\hline bid-ask spread & -0.37 & -0.08 & 0.09 & 0.05 & 0.07 & 0.02 \\
\hline
\end{tabular}

Note: Sample period: 1 Jan 1998 - 1 July 1999. All variables are expressed in percentage changes. Historical volatilities are computed with daily data over rolling windows of 20 business days. Bid-ask spreads are expressed as a percentage of the exchange rate. 
Table 5

Summary statistics for one-month historical volatility

\begin{tabular}{|l|c|l|l|l|}
\hline & Mean & Std dev & Min & Max \\
\hline Colombian peso & 7.94 & 4.66 & 1.64 & 21.97 \\
Mexican peso & 10.53 & 5.83 & 3.28 & 27.3 \\
Rand & 13.11 & 10.2 & 2.09 & 49.2 \\
Real & 10.98 & 18.24 & 0.56 & 76.15 \\
Real (1.1.-1.7.1999) & 30.54 & 20.69 & 6.61 & 76.15 \\
Rupee & 3.73 & 2.75 & 0.69 & 10.66 \\
Rupiah & 55.47 & 38.85 & 8.35 & 175.26 \\
Shekel & 6.55 & 4.08 & 2.09 & 21.2 \\
Memo item: & & & & \\
Yen/dollar & 15.33 & 5.51 & 7.76 & 32.46 \\
\hline
\end{tabular}

Note: Sample period: 1 Jan 1998 - 1 July 1999. Historical volatilities are computed with daily data over rolling windows of 20 business days.

Table 6

Test for ARCH effects for percentage exchange rate changes

\begin{tabular}{|c|c|c|c|c|}
\hline Lags & 1 & 2 & 5 & 10 \\
\hline Colombian peso & 0.00 & 0.03 & 0.44 & $11.77 * *$ \\
\hline Mexican peso & $16.25 * *$ & $21.18^{* *}$ & $83.95 * *$ & $83.8^{* *}$ \\
\hline Rand & $8.1 * *$ & $9.73 * *$ & $59.16 * *$ & $75.56^{* *}$ \\
\hline Real & $15.69 * *$ & $15.35^{* *}$ & $24.33 * *$ & $40.3 * *$ \\
\hline \multicolumn{5}{|l|}{ Rupee } \\
\hline Rupiah & $16.82^{* *}$ & $23.89 * *$ & $67.72 * *$ & $46.27 * *$ \\
\hline Shekel & $25.3 * *$ & $71.2 * *$ & $74.13 * *$ & $75.6^{* *}$ \\
\hline
\end{tabular}


Table 7

Regressions of volatility on a linear trend

\begin{tabular}{|c|c|c|c|c|}
\hline & Constant & Time & Dummy & $\mathbf{R}^{2}$ \\
\hline Colombian peso & $\begin{array}{c}-0.63 * \\
(-1.94)\end{array}$ & $\begin{array}{l}0.001 * * \\
(3.69)\end{array}$ & $\begin{array}{l}-0.09 \\
(0.72)\end{array}$ & 0.01 \\
\hline Mexican peso & $\begin{array}{c}0.45 \\
(0.98)\end{array}$ & $\begin{array}{c}0.00 \\
(0.30)\end{array}$ & $\begin{array}{c}-0.06 \\
(-0.39)\end{array}$ & 0.01 \\
\hline Rand & $\begin{array}{l}2.74 * \\
(1.94)\end{array}$ & $\begin{array}{l}-0.001 \\
(-1.34)\end{array}$ & $\begin{array}{c}-0.54 \\
(-1.55)\end{array}$ & 0.01 \\
\hline $\operatorname{Real}(1)$ & $\begin{array}{c}-11.95 * * \\
(-4.14)\end{array}$ & $\begin{array}{l}0.01 * * \\
(4.02)\end{array}$ & $\begin{array}{c}-1.02 \\
(-1.19)\end{array}$ & 0.02 \\
\hline Rupee & $\begin{array}{l}0.60 * * \\
(3.00)\end{array}$ & $\begin{array}{l}-0.00 * * \\
(-2.76)\end{array}$ & $\begin{array}{c}0.06 \\
(0.89)\end{array}$ & 0.03 \\
\hline Rupiah & $\begin{array}{c}177.22 * * \\
(4.94)\end{array}$ & $\begin{array}{l}-0.16^{* *} \\
(-4.81)\end{array}$ & $\begin{array}{c}-4.38 \\
(-0.86)\end{array}$ & 0.11 \\
\hline Shekel & $\begin{array}{c}0.13 \\
(1.01)\end{array}$ & $\begin{array}{l}0.0001 \\
(0.90)\end{array}$ & $\begin{array}{c}0.03 \\
(0.41)\end{array}$ & 0.01 \\
\hline $\begin{array}{l}\text { Memo item: } \\
\text { Yen/dollar }\end{array}$ & $\begin{array}{l}1.18^{*} \\
(1.93)\end{array}$ & $\begin{array}{c}-0.00 \\
(-0.15)\end{array}$ & $\begin{array}{c}-0.31 \\
(-1.42)\end{array}$ & 0.01 \\
\hline \multicolumn{5}{|c|}{$\begin{array}{l}\text { Note: Regressions of volatility, computed as squared returns, on a linear time trend over the } \\
\text { sample period } 1 \text { Jan } 1998 \text { - } 1 \text { July 1999. T-statistics are in parentheses. Trading volumes are } \\
\text { expressed in US\$ millions. (1) Sample period: 1Jan } 1999 \text { - 1 July } 1999 .\end{array}$} \\
\hline
\end{tabular}

Table 8

Summary statistics for forex trading volumes

\begin{tabular}{|l|llll|}
\hline & Mean & Std dev & Min & Max \\
\hline Colombian peso: & & & & \\
Trading volume & 165 & 72 & 16 & 362 \\
Colombian peso: & & & & \\
Number of trades per day & 231 & 102.7 & 29 & 452 \\
Mexican peso & 8,827 & 2,281 & 635 & 15,812 \\
Rand & 9,535 & 2,410 & 3,432 & 21,568 \\
Real & 10,849 & 4,090 & 2,671 & 31,219 \\
Real(1) & 8,153 & 2,549 & 3,051 & 16,965 \\
Rupee & 3,478 & 1,351 & 1 & 8,211 \\
Rupiah & 1,072 & 250 & 611 & 1,871 \\
Shekel & 772 & 244 & 5 & 1,698 \\
Memo item: & & & & \\
Yen/dollar (2) & 12,944 & 4,453 & 1,737 & 41,341 \\
\hline
\end{tabular}

Note: Average daily turnover, in US\$ millions. Sample period: 1 Jan 1998 - 30 June 1999. (1) Sample period: 1 Jan 1999 - 1 July 1999. (2) Traded on the Tokyo interbank market. In April 1998 , average daily global turnover for yen/dollar transactions amounted to US\$267 billion. Total forex turnover in April 1998 was \$1,500 billion. 
Table 9

Summary statistics for exchange-traded volumes

\begin{tabular}{|l|llll|}
\hline Series & Mean & Std Dev & Min & Max \\
\hline Real & 16 & 35 & 0 & 277 \\
Real (1) & 224 & 484.27 & 0 & 4,164 \\
Mexican peso & 247 & 160 & 0 & 934 \\
Mexican peso (1) & 4,632 & $2,968.35$ & 0 & 17,076 \\
Rand & 12 & 22 & 0 & 270 \\
Rand (1) & 142 & 275.35 & 0 & 3,361 \\
\hline $\begin{array}{l}\text { Note: Notional values, in US\$ millions. Sample period: January 1998 - June 1999. (1) Number of deals per } \\
\text { day. }\end{array}$
\end{tabular}

Table 10

Summary statistics for percentage changes of OTC trading volumes

\begin{tabular}{|l|c|c|l|l|l|l|l|}
\hline & Mean & Std dev & $\begin{array}{l}\text { Test mean } \\
\mathbf{0}\end{array}$ & Skewness & Kurtosis & Min & Max \\
\hline Colombian peso & 7.5 & 45.16 & $3.17(0)$ & 2.95 & 20.17 & -84.02 & 411.72 \\
Colombian peso (2) & 6.97 & 47.6 & $2.8(0)$ & 4.54 & 38.93 & -81.77 & 505.71 \\
Mexican peso & 12.78 & 109.09 & $2.3(0.02)$ & 10.34 & 126.58 & -93.04 & $1,542.37$ \\
Rand & 2.65 & 26.24 & $1.6(0.11)$ & 1.24 & 4.4 & -64.2 & 141.19 \\
Real (1) & 5.48 & 38.24 & $1.6(0.12)$ & 4.9 & 38.32 & -73.49 & 318.59 \\
Rupee & & & & & & & \\
Rupiah & 3.20 & 27.24 & $1.2(0.25)$ & 0.52 & -0.13 & -50.27 & 68.44 \\
Shekel & 4.05 & 30.70 & $4.6(0)$ & 7.73 & 85.99 & -100.00 & 104.77 \\
Memo item: & 7.98 & 46.6 & $3.6(0)$ & 2.77 & 13.78 & -78.06 & 346.88 \\
Yen/dollar (3) & & & & & & \\
\hline
\end{tabular}

Note: Sample period: January 1998 - June 1999. (1) Sample period 1 January 1999 - 1 July 1999. (2) Number of deals per day. (3) Traded on the Tokyo interbank market. 
Table 11

Regressions of trading volumes on a linear trend

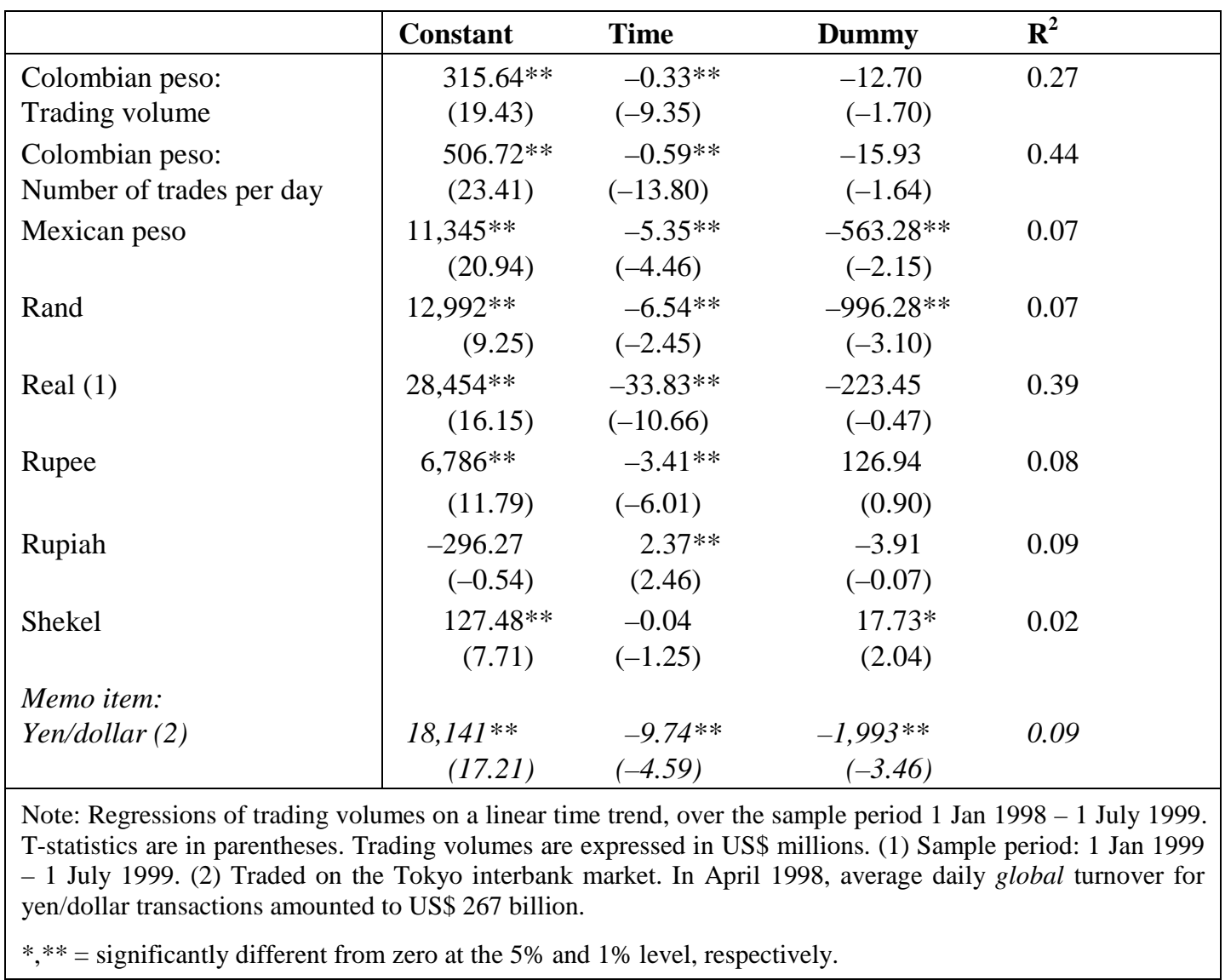

Table 12

\section{Summary statistics for bid-ask spreads}

\begin{tabular}{|l|l|l|l|l|}
\hline & Mean & Std dev & Min & Max \\
\hline Colombian peso & na & na & na & na \\
Mexican peso & 0.12 & 0.08 & 0.02 & 0.94 \\
Rand & 0.20 & 0.63 & 0.01 & 12.27 \\
Real & 0.16 & 0.32 & 0.01 & 2.68 \\
Real (1.1.-1.7.1999) & 0.44 & 0.44 & 0.01 & 2.70 \\
Rupee & 0.37 & 0.23 & 0.00 & 2.36 \\
Rupiah & 2.11 & 1.49 & 0.14 & 8.70 \\
Shekel & 0.29 & 0.16 & 0.12 & 1.18 \\
$\begin{array}{l}\text { Memo item: } \\
\text { Yen/dollar }\end{array}$ & 0.05 & 0.02 & 0.02 & 0.09 \\
\hline $\begin{array}{l}\text { Note: Sample period: 1 Jan 1998 } \\
\text { rate. The data source is DRI. }\end{array}$ & 1 July 1999. Bid-ask spreads are expressed as a percentage of the exchange \\
\hline
\end{tabular}


Table 13

Summary statistics for percentage changes of bid-ask spreads

\begin{tabular}{|l|c|c|c|c|c|c|c|}
\hline & Mean & Std dev & $\begin{array}{l}\text { Test mean } \\
\mathbf{=}\end{array}$ & Skewness & Kurtosis & Min & Max \\
\hline Colombian peso & na & na & na & na & na & na & na \\
Mexican peso & 18.44 & 87.47 & $4.15(0)$ & 4.15 & 4.15 & -84.9 & 853 \\
Rand & 34.4 & 401.6 & $1.68(0.1)$ & 18.55 & 357.1 & -97.3 & 7763 \\
Real & 40.4 & 258.7 & & & & -92.3 & 3491 \\
Real & 69.57 & 417.68 & $1.89(0.06)$ & 6.71 & 46.76 & -84.8 & $3,443.98$ \\
$(1.1 .-1.7 .1999)$ & & & & & & & \\
Rupee & 0.03 & 0.29 & 1.81 & -0.24 & 20.3 & -2.13 & 2.01 \\
& & & $(0.07)$ & $(0)$ & $(0)$ & & 15,0148 \\
Rupiah & 521.54 & 7,999 & $1.28(0.2)$ & 17.5 & 322.17 & $-1,056$ & 135.12 \\
Shekel & 4.07 & 28.8 & $2.78(0)$ & 1 & 2.31 & -57.3 & \\
$\begin{array}{l}\text { Memo item: } \\
\text { Yen/dollar }\end{array}$ & 12.9 & 58.4 & $4.3(0)$ & 1.39 & 2.38 & -70.3 & 237.1 \\
\hline
\end{tabular}

Table 14

Correlations

\begin{tabular}{|c|c|c|c|c|c|c|c|c|c|}
\hline & $\begin{array}{c}\Delta \mathrm{xr}, \\
\text { volume }\end{array}$ & $\begin{array}{c}\Delta^{+} \mathrm{xr}, \\
\text { volume }\end{array}$ & $\begin{array}{c}\Delta \mathrm{xr}, \\
\text { volume }\end{array}$ & $\begin{array}{l}|\Delta X R|, \\
\text { volume }\end{array}$ & $\begin{array}{c}\text { Volatility, } \\
\text { volume }\end{array}$ & $\begin{array}{c}\text { Hist vol, } \\
\text { volume }\end{array}$ & $\begin{array}{c}\Delta \mathrm{xr}, \\
\text { spread }\end{array}$ & $\begin{array}{l}\text { Spread, } \\
\text { volume }\end{array}$ & $\begin{array}{c}\text { Spread, } \\
\text { volatility }\end{array}$ \\
\hline $\begin{array}{l}\text { Colombian peso: } \\
\text { Trading volume }\end{array}$ & 0.08 & 0.14 & 0.05 & 0.08 & 0.09 & 0.01 & na & na & na \\
\hline $\begin{array}{l}\text { Colombian peso: } \\
\text { Number of trades } \\
\text { per day }\end{array}$ & 0.13 & 0.15 & 0.03 & & & 0.13 & na & na & na \\
\hline Mexican peso & 0.06 & -0.10 & 0.17 & -0.11 & -0.10 & -0.28 & 0.26 & -0.15 & 0.64 \\
\hline Rand & 0.16 & 0.27 & -0.11 & 0.20 & 0.14 & -0.08 & 0.15 & -0.05 & 0.14 \\
\hline Real & -0.17 & -0.42 & 0.26 & -0.37 & -0.21 & -0.57 & 0.31 & -0.47 & 0.56 \\
\hline $\begin{array}{l}\text { Real } \\
(1.1 .-1.7 .1999)\end{array}$ & -0.25 & -0.31 & -0.02 & -0.05 & -0.01 & -0.28 & 0.32 & -0.30 & 0.35 \\
\hline Rupee & 0.10 & 0.37 & -0.35 & 0.38 & 0.28 & 0.40 & 0.13 & 0.38 & 0.38 \\
\hline Rupiah & -0.09 & 0.17 & -0.30 & 0.21 & 0.10 & -0.02 & -0.05 & -0.20 & 0.30 \\
\hline Shekel & 0.04 & 0.30 & -0.27 & 0.28 & 0.25 & 0.09 & 0.17 & 0.16 & 0.43 \\
\hline Memo item: & & & & & & & & & \\
\hline Yen/dollar & -0.16 & 0.47 & -0.45 & 0.45 & 0.40 & 0.15 & -0.09 & 0.08 & 0.08 \\
\hline
\end{tabular}


Table 15

Correlations for exchange-traded volumes

\begin{tabular}{|l|c|c|c|c|c|c|c|}
\hline & $\begin{array}{c}\boldsymbol{\Delta} \mathbf{x r}, \\
\text { volume }\end{array}$ & $\begin{array}{c}\boldsymbol{\Lambda}^{+} \mathbf{x r}, \\
\text { volume }\end{array}$ & $\begin{array}{c}\boldsymbol{\Delta} \mathbf{x r}, \\
\text { volume }\end{array}$ & $\begin{array}{c}|\boldsymbol{\Delta} \mathbf{X R}|, \\
\text { volume }\end{array}$ & $\begin{array}{c}\text { Volatility, } \\
\text { volume }\end{array}$ & $\begin{array}{c}\text { Hist vol, } \\
\text { volume }\end{array}$ & $\begin{array}{c}\text { Spread, } \\
\text { volume }\end{array}$ \\
\hline Mexican peso & 0.09 & 0.28 & -0.11 & 0.22 & 0.16 & 0.04 & 0.07 \\
\hline
\end{tabular}

Table 16

Volatility and trading volume: unconditional regressions

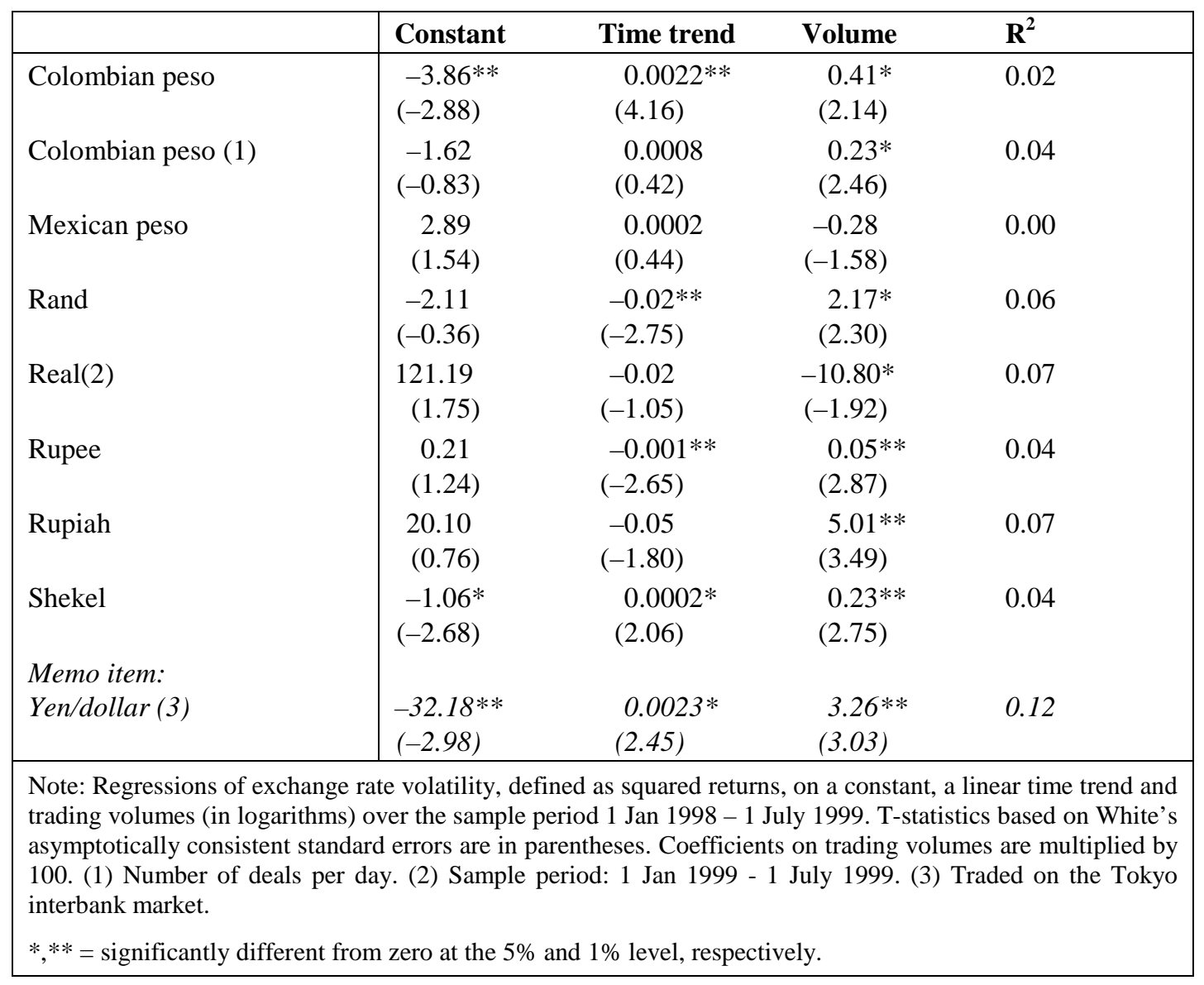


Table 17

Trading volumes and volatility

\begin{tabular}{|c|c|c|c|c|}
\hline & Constant & $E(v)$ & $v-E(v)$ & $\mathbf{R}^{2}$ \\
\hline Colombian peso & $\begin{array}{c}-4.04 \\
-(2.47)\end{array}$ & $\begin{array}{c}0.44 \\
(1.91)\end{array}$ & $\begin{array}{l}0.34^{*} \\
(2.27)\end{array}$ & 0.02 \\
\hline Mexican peso & $\begin{array}{c}3.09 \\
(0.82)\end{array}$ & $\begin{array}{c}-0.28 \\
(-0.78)\end{array}$ & $\begin{array}{c}-0.30 \\
(-1.50)\end{array}$ & 0.00 \\
\hline Rand & $\begin{array}{c}7.50 \\
(0.66)\end{array}$ & $\begin{array}{c}1.31 \\
(0.98)\end{array}$ & $\begin{array}{l}3.08 * \\
(2.47)\end{array}$ & 0.07 \\
\hline $\operatorname{Real}(1)$ & $\begin{array}{l}69.93 \\
(1.04)\end{array}$ & $\begin{array}{l}14.28 \\
(1.26)\end{array}$ & $\begin{array}{c}-2.83 \\
(-0.62)\end{array}$ & 0.15 \\
\hline Rupee & $\begin{array}{l}-1.70 * * \\
(-2.74)\end{array}$ & $\begin{array}{l}0.29 * * \\
(3.16)\end{array}$ & $\begin{array}{l}0.04 * * \\
(2.91)\end{array}$ & 0.05 \\
\hline Rupiah & $\begin{array}{l}17.41 \\
(0.41)\end{array}$ & $\begin{array}{c}5.32 \\
(1.19)\end{array}$ & $\begin{array}{l}4.97 * * \\
(2.96)\end{array}$ & 0.07 \\
\hline Shekel & $\begin{array}{l}-2.63 * * \\
(-2.87)\end{array}$ & $\begin{array}{l}0.56 * * \\
(2.91)\end{array}$ & $\begin{array}{l}0.18 * * \\
(2.65)\end{array}$ & 0.05 \\
\hline $\begin{array}{l}\text { Memo item: } \\
\text { Yen/dollar (2) }\end{array}$ & $\begin{array}{c}-27.27 * \\
(-2.04)\end{array}$ & $\begin{array}{l}2.78 * \\
(2.03) \\
\end{array}$ & $\begin{array}{l}3.20 * * \\
(3.06)\end{array}$ & 0.11 \\
\hline \multicolumn{5}{|c|}{$\begin{array}{l}\text { Note: Regressions of total volatility on a constant, a linear time trend, expected volumes and unexpected volumes. } \\
\text { Sample period: } 1 \text { Jan } 1998-1 \text { July } 1999 \text {. Total volatility is defined as squared returns; log volumes are } \\
\text { decomposed into an expected and an unexpected component by using a fitted AR series and its residuals. } \\
\text { T-statistics based on White's asymptotically consistent standard errors are in parentheses. (1) Sample period: } 1 \text { Jan } \\
1999 \text { - } 1 \text { July 1999. (2) Traded on the Tokyo interbank market. } \\
* * * \text { significantly different from zero at the } 5 \% \text { and } 1 \% \text { level, respectively. }\end{array}$} \\
\hline
\end{tabular}


Table 18

Trading volumes and volatility

\begin{tabular}{|c|c|c|c|c|c|}
\hline & Constant & GARCH & $E(v)$ & $v-E(v)$ & $\mathbf{R}^{2}$ \\
\hline Colombian peso & $\begin{array}{c}-3.53 \\
(-1.85)\end{array}$ & $\begin{array}{c}0.01 \\
(1.03)\end{array}$ & $\begin{array}{c}0.39 \\
(1.50)\end{array}$ & $\begin{array}{l}0.34^{*} \\
(2.22)\end{array}$ & 0.02 \\
\hline Mexican peso & $\begin{array}{c}-0.03 \\
(-0.01)\end{array}$ & $\begin{array}{l}0.08 * * \\
(2.89)\end{array}$ & $\begin{array}{c}-0.64 \\
(-0.18)\end{array}$ & $\begin{array}{l}-0.28 \\
(-1.50)\end{array}$ & 0.09 \\
\hline Rand & $\begin{array}{c}7.19 \\
(0.62)\end{array}$ & $\begin{array}{c}0.09 \\
(1.66)\end{array}$ & $\begin{array}{c}0.14 \\
(0.10)\end{array}$ & $\begin{array}{c}3.04 * \\
(2.27)\end{array}$ & 0.10 \\
\hline Real(1) & $\begin{array}{c}-83.43 \\
(-0.69)\end{array}$ & $\begin{array}{c}0.23 \\
(1.73)\end{array}$ & $\begin{array}{l}20.27 \\
(1.57)\end{array}$ & $\begin{array}{l}-1.69 \\
(-0.36)\end{array}$ & 0.20 \\
\hline Rupee & $\begin{array}{c}-1.47^{*} \\
(-2.22)\end{array}$ & $\begin{array}{c}0.01 \\
(1.06)\end{array}$ & $\begin{array}{l}0.24 * \\
(2.47)\end{array}$ & $\begin{array}{c}0.04 * \\
(2.53)\end{array}$ & 0.05 \\
\hline Rupiah & $\begin{array}{l}17.09 \\
(0.41)\end{array}$ & $\begin{array}{c}-0.00 \\
(-0.08)\end{array}$ & $\begin{array}{c}5.16 \\
(1.02)\end{array}$ & $\begin{array}{l}5.00 * * \\
(2.76)\end{array}$ & 0.07 \\
\hline Shekel & $\begin{array}{c}-0.90 \\
(-1.44)\end{array}$ & $\begin{array}{l}0.08 * * \\
(3.52)\end{array}$ & $\begin{array}{c}0.14 \\
(1.02)\end{array}$ & $\begin{array}{c}0.08 \\
(1.51)\end{array}$ & 0.19 \\
\hline $\begin{array}{l}\text { Memo item: } \\
\text { Yen/dollar (2) }\end{array}$ & $\begin{array}{c}-14.50 \\
(-1.47)\end{array}$ & $\begin{array}{c}0.11 \\
(1.90)\end{array}$ & $\begin{array}{c}1.31 \\
(1.31)\end{array}$ & $\begin{array}{l}2.93 * * \\
(3.23)\end{array}$ & 0.13 \\
\hline \multicolumn{6}{|c|}{$\begin{array}{l}\text { Note: Regressions of total volatility on a constant, a linear time trend, expected volatility, expected volumes and unexpected } \\
\text { volumes. Sample period: } 1 \text { Jan } 1998-1 \text { July } 1999 \text {. Total volatility is defined as squared returns; expected volatility is the one- } \\
\text { step-ahead conditional return variance from a GARCH(1,1) specification; log volumes are decomposed into an expected and } \\
\text { an unexpected component by using a fitted AR series and its residuals. T-statistics based on White's asymptotically consistent } \\
\text { standard errors are in parentheses. (1) Sample period: } 1 \text { Jan } 1999-1 \text { July 1999. (2) Traded on the Tokyo interbank market. } \\
*, * *=\text { significantly different from zero at the } 5 \% \text { and } 1 \% \text { level, respectively. }\end{array}$} \\
\hline
\end{tabular}


Table 19

Spreads, trading volumes and volatility

\begin{tabular}{|c|c|c|c|c|c|}
\hline & Constant & GARCH & $\mathbf{E}(v)$ & $v-E(v)$ & $\mathbf{R}^{2}$ \\
\hline Colombian peso & na & na & na & na & na \\
\hline Mexican peso & $\begin{array}{l}0.47 * * \\
(2.83)\end{array}$ & $\begin{array}{l}0.01 * * \\
(5.32)\end{array}$ & $\begin{array}{l}-0.05 * * \\
(-2.65)\end{array}$ & $\begin{array}{c}-0.01 \\
(-1.21)\end{array}$ & 0.20 \\
\hline Rand & $\begin{array}{c}0.96 \\
(1.42)\end{array}$ & $\begin{array}{c}0.01 \\
(1.50)\end{array}$ & $\begin{array}{c}-0.10 \\
(-1.45)\end{array}$ & $\begin{array}{c}-0.16 \\
(-1.09)\end{array}$ & 0.05 \\
\hline $\operatorname{Real}(1)$ & $\begin{array}{c}-0.10 \\
(-0.06)\end{array}$ & $\begin{array}{l}0.01 * * \\
(7.31)\end{array}$ & $\begin{array}{c}0.02 \\
(0.13)\end{array}$ & $\begin{array}{c}-0.26 \\
(-0.99)\end{array}$ & 0.47 \\
\hline Rupee & $\begin{array}{c}0.15 \\
(0.22)\end{array}$ & $\begin{array}{l}0.03 * * \\
(6.81)\end{array}$ & $\begin{array}{c}0.01 \\
(0.16)\end{array}$ & $\begin{array}{c}0.02 \\
(1.61)\end{array}$ & 0.22 \\
\hline Rupiah & $\begin{array}{c}7.77 \\
(1.73)\end{array}$ & $\begin{array}{l}0.01 * \\
(2.28)\end{array}$ & $\begin{array}{c}-1.01 \\
(-1.55)\end{array}$ & $\begin{array}{c}-0.44 \\
(-1.74)\end{array}$ & 0.10 \\
\hline Shekel & $\begin{array}{l}0.23^{*} \\
(2.13)\end{array}$ & $\begin{array}{c}0.03 * * \\
(14.40)\end{array}$ & $\begin{array}{c}-0.03 \\
(-1.42)\end{array}$ & $\begin{array}{c}-0.01 \\
(-0.95)\end{array}$ & 0.62 \\
\hline $\begin{array}{l}\text { Memo item: } \\
\text { Yen/dollar (2) }\end{array}$ & $\begin{array}{c}0.08 \\
(1.18)\end{array}$ & $\begin{array}{c}0.00 \\
(1.25)\end{array}$ & $\begin{array}{c}-0.00 \\
(-0.48)\end{array}$ & $\begin{array}{c}0.00 \\
(0.54)\end{array}$ & 0.02 \\
\hline
\end{tabular}

Note: Regressions of bid-ask spreads on expected volatility, expected volumes and unexpected volumes estimated over the sample period 1 Jan 1998 - 1 July 1999. Total volatility is defined as squared returns; expected volatility is the one-step-ahead conditional return variance from a $\operatorname{GARCH}(1,1)$ specification; volumes are decomposed into an expected and an unexpected component by using a fitted AR(1) series and its residuals. T-statistics based on White's asymptotically consistent standard errors are in parentheses. (1) Sample period: 1 Jan 1999 - 1 July 1999. (2) Traded on the Tokyo interbank market.

$*, * *=$ significantly different from zero at the $5 \%$ and $1 \%$ level, respectively. 
Graph 1

Trading volumes, volatility and spreads

BRAZIL
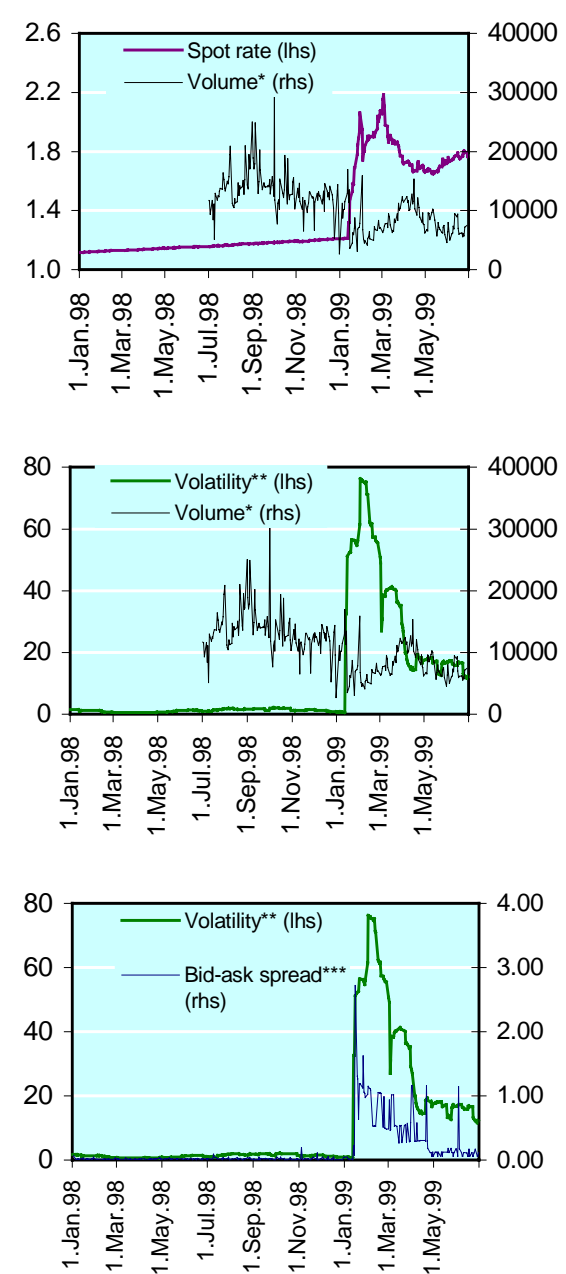

COLOMBIA
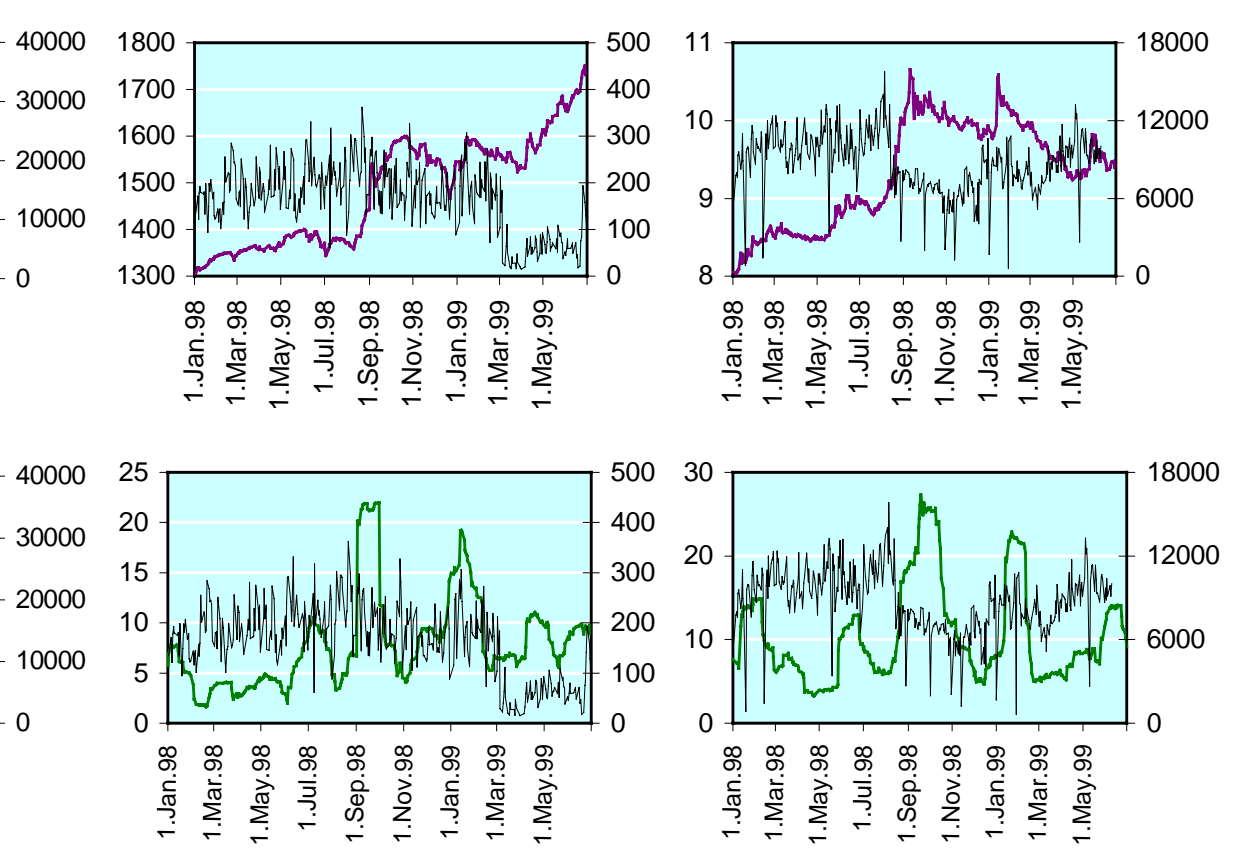

JAPAN

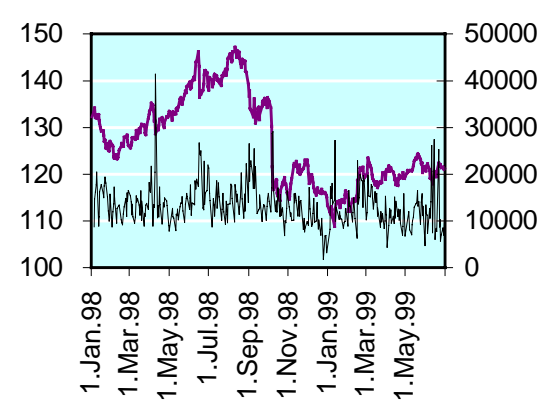

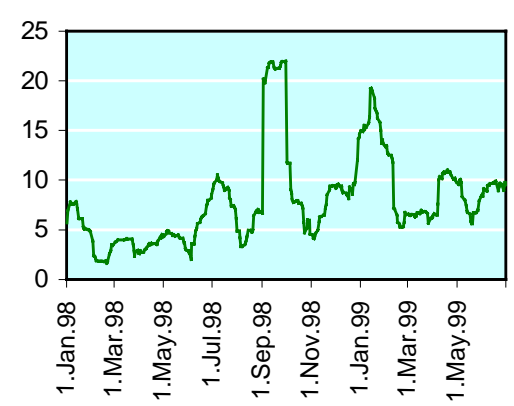
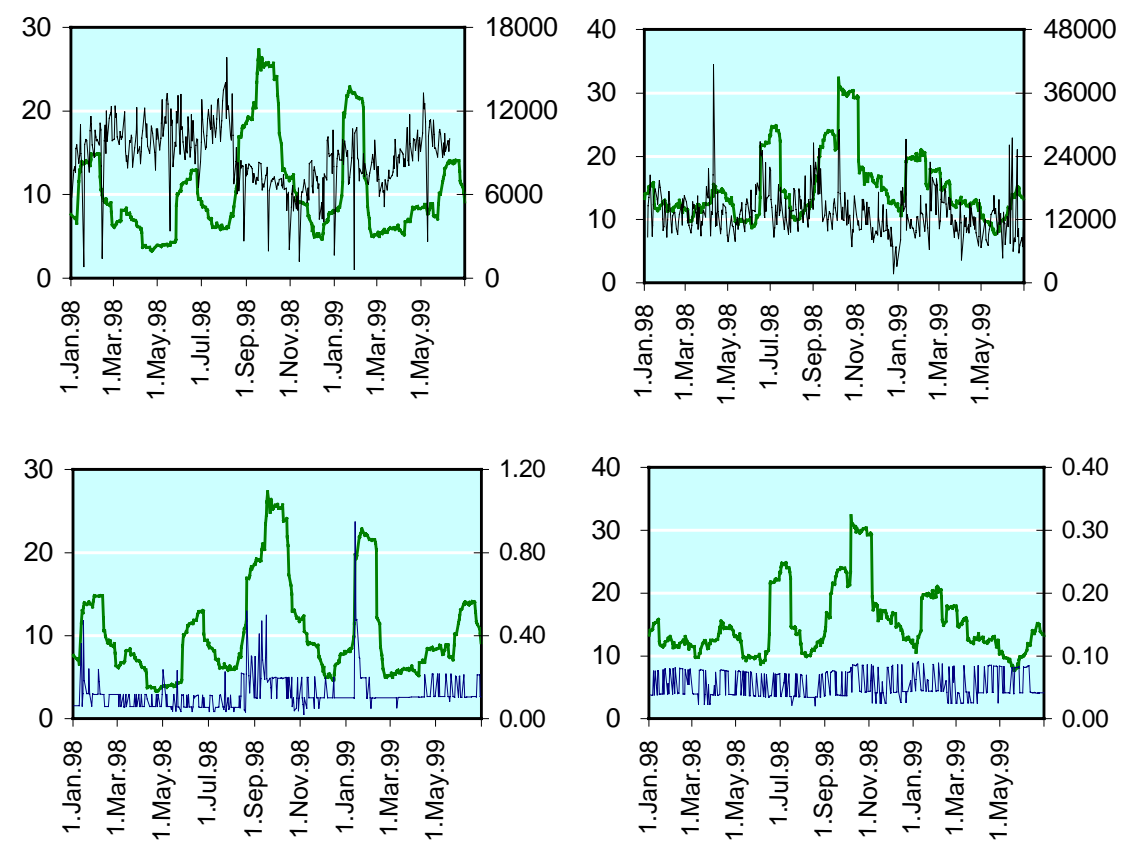

* Expressed in million US\$. ${ }^{* \star} 1$-month historical volatility. ${ }^{* \star}$ As a percentage of the mid quote. 
Graph 1 (continued)

Trading volumes, volatility and spreads
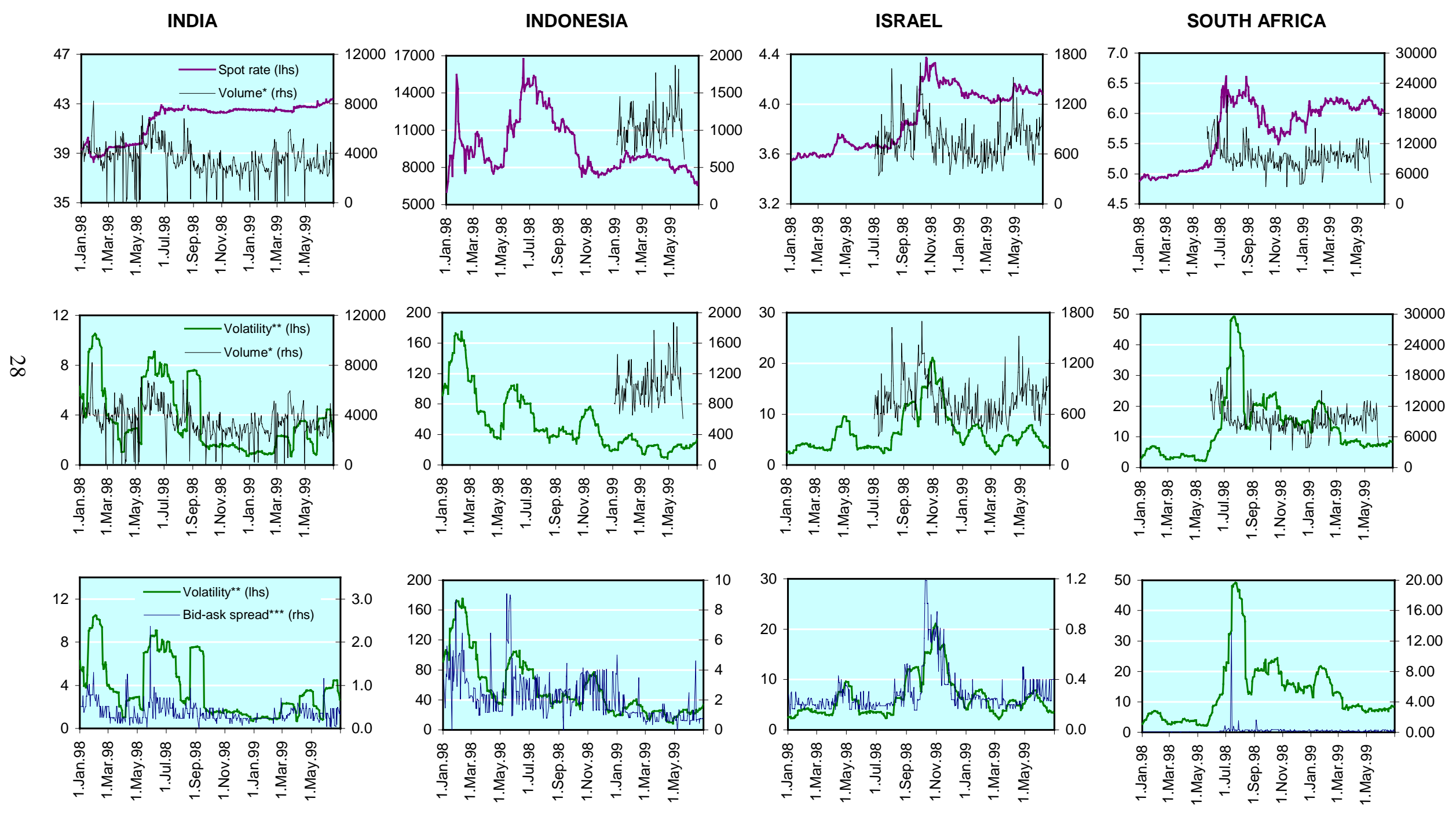

${ }^{*}$ Expressed in million US\$. ${ }^{* *} 1$-month historical volatility. ${ }^{* * *}$ As a percentage of the mid quote. 
Graph 2

Trading volumes and volatility in selected emerging markets
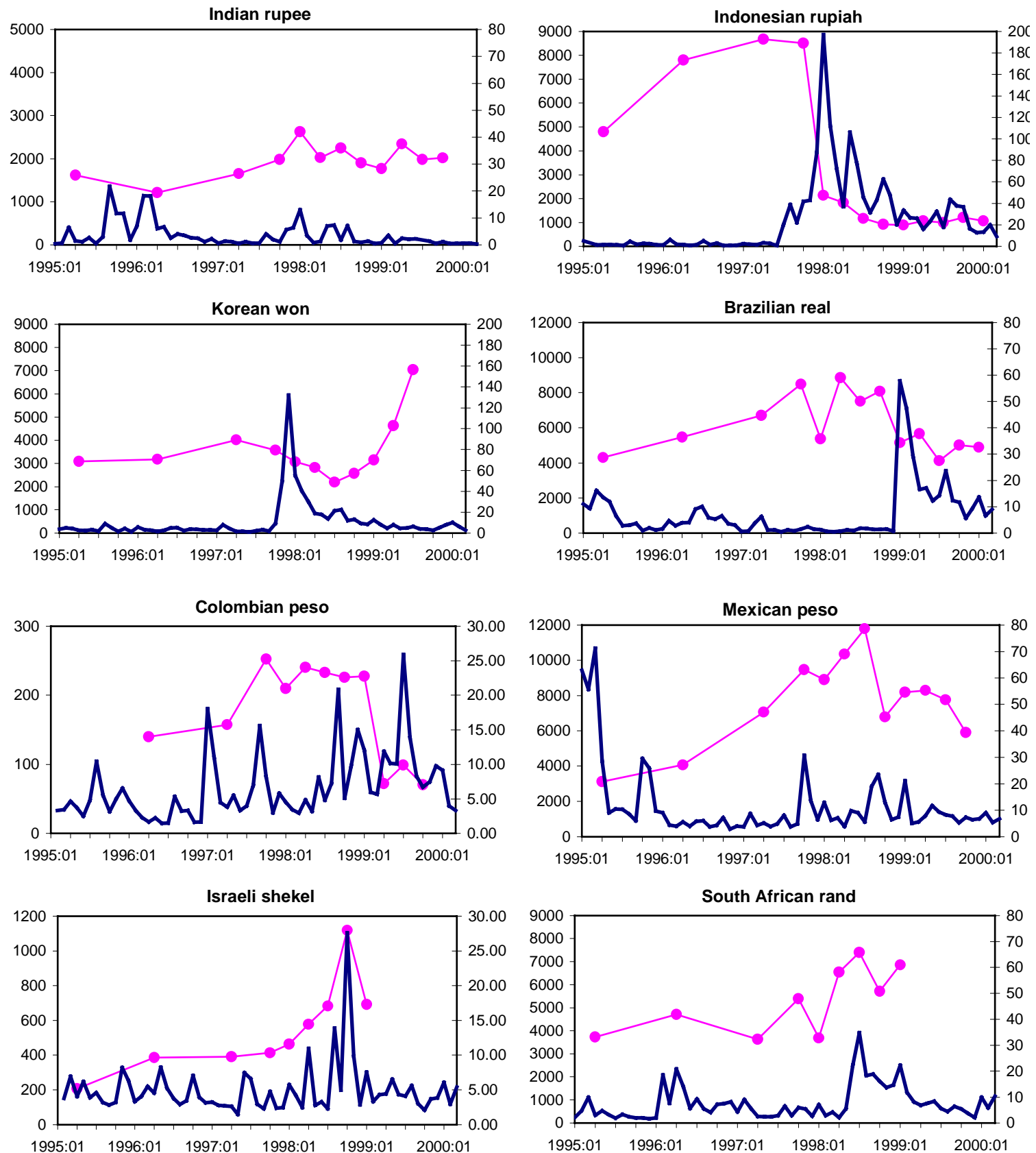

Note: Trading volumes refer to local turnover in the domestic currency, per trading day in the month shown (in millions of US dollars). In the case of Mexico and Brazil, turnover includes other currencies. Volatility is computed as the one-month annualised standard deviation of percentage changes in the exchange rate against the US dollar. 
Graph 3

OTC and exchange-traded foreign exchange market turnover
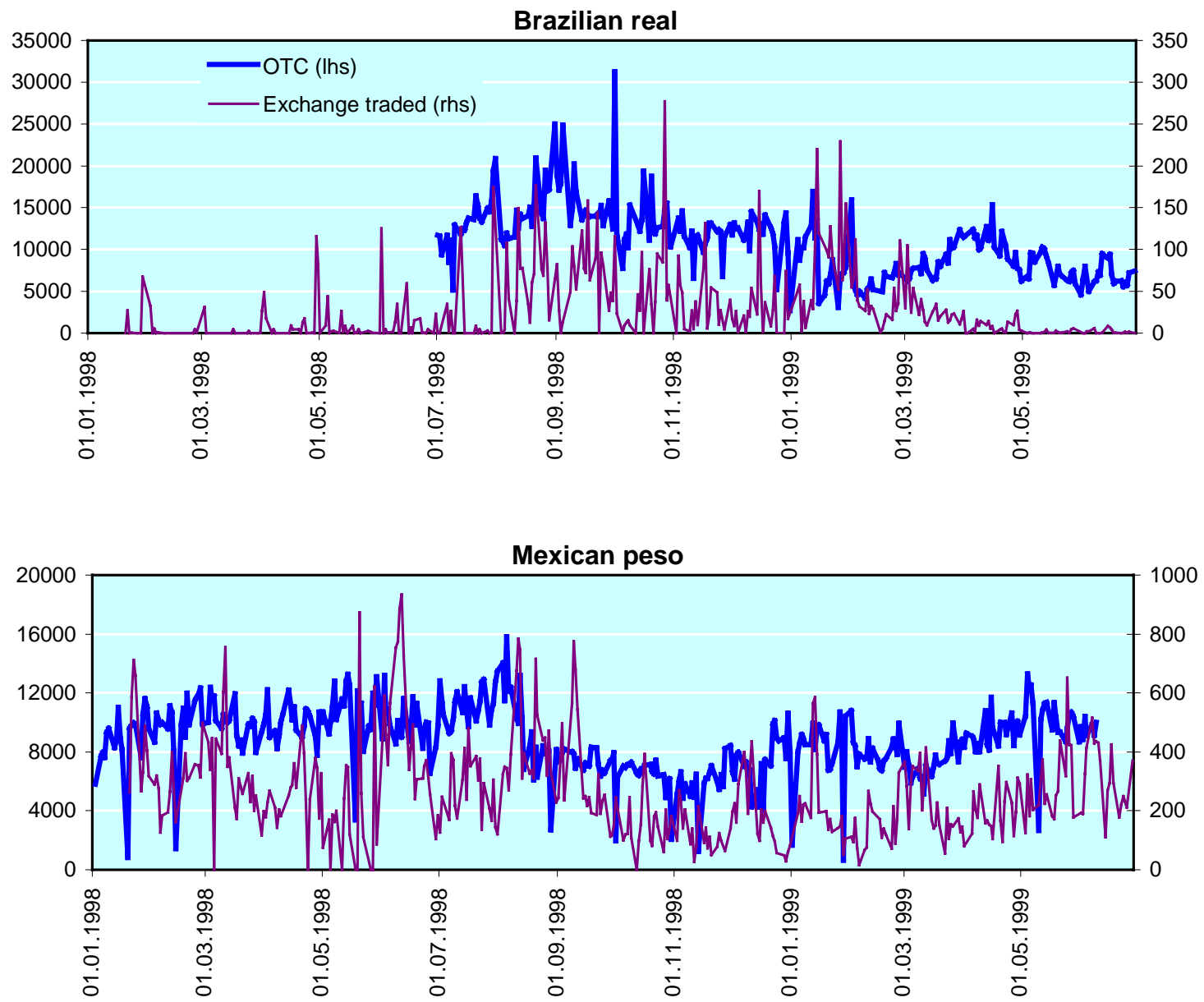

South African rand

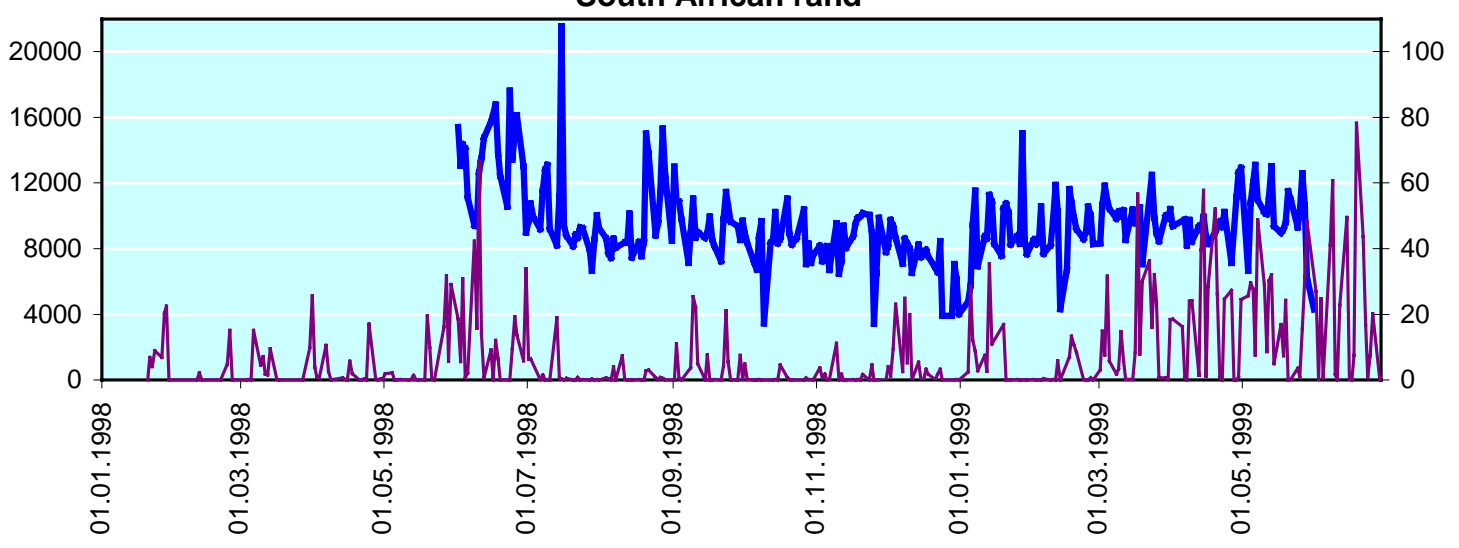

Note: OTC turnover is defined as in Graph 1. Exchange-traded turnover refers to notional values of futures contracts transacted on the Chicago Mercantile Exchange. 
Graph 4

\section{Rolling correlations}
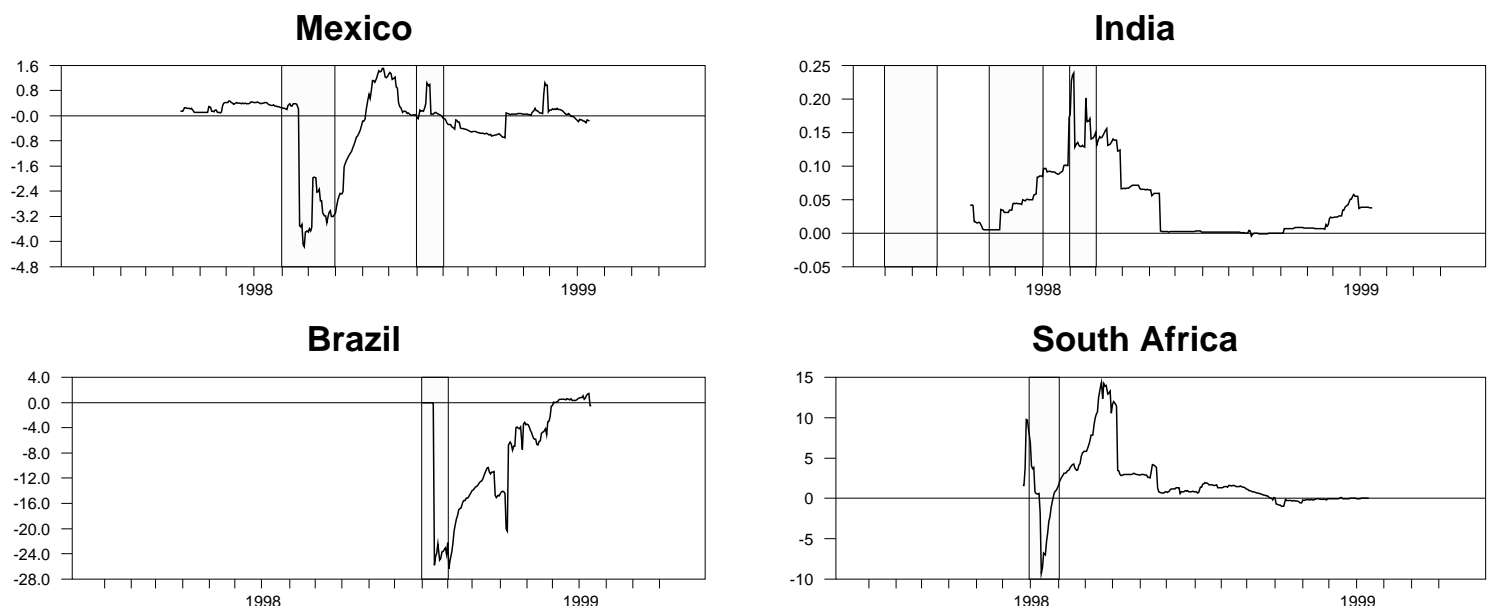

South Africa

\section{Colombia}

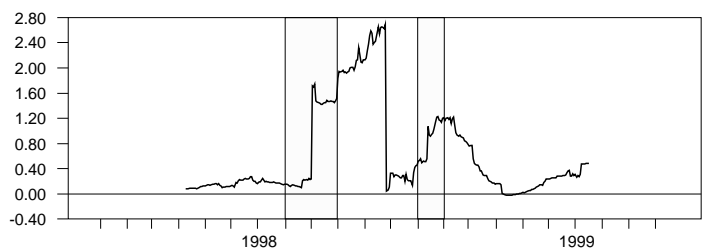

Indonesia
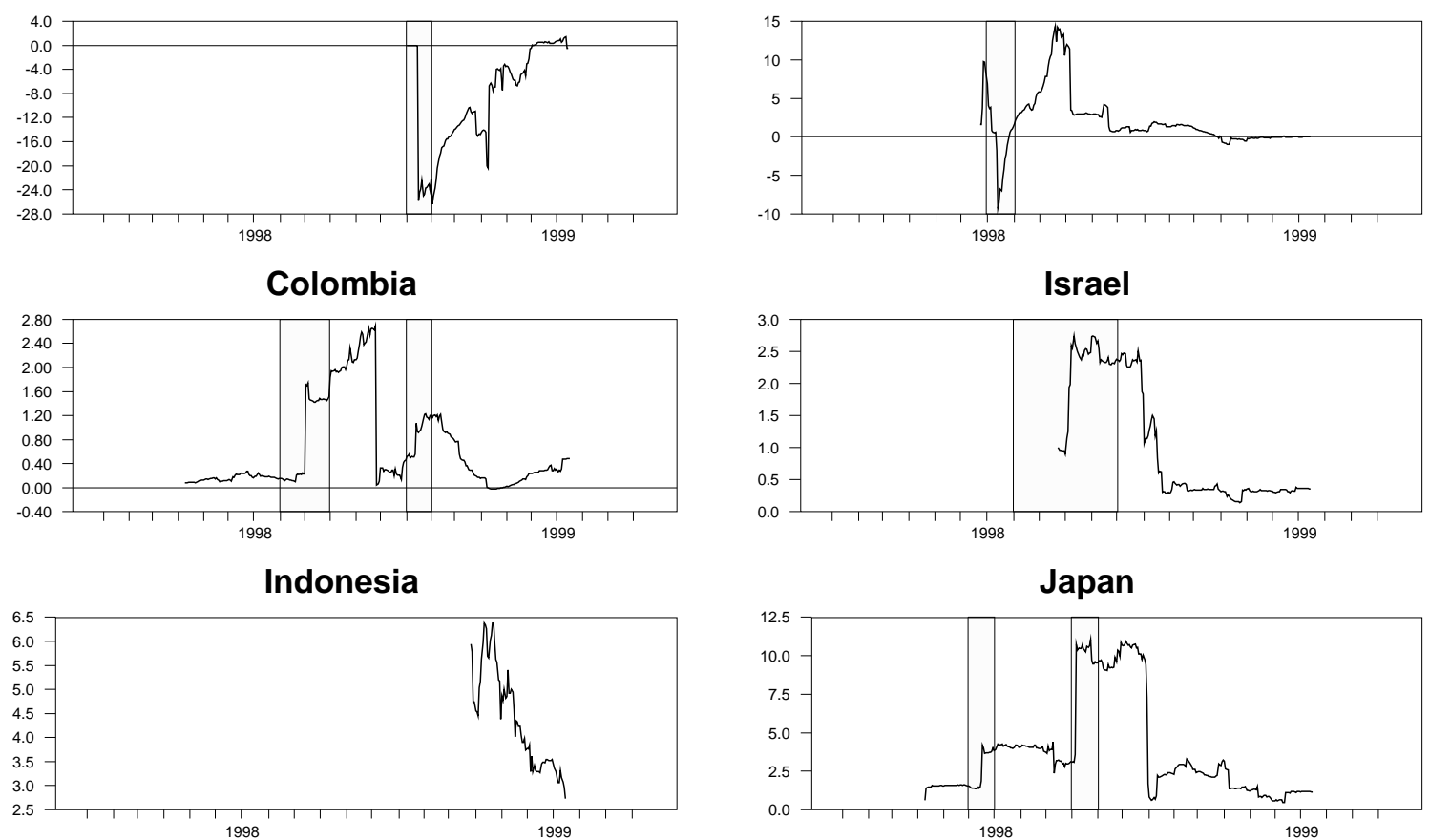

Israel
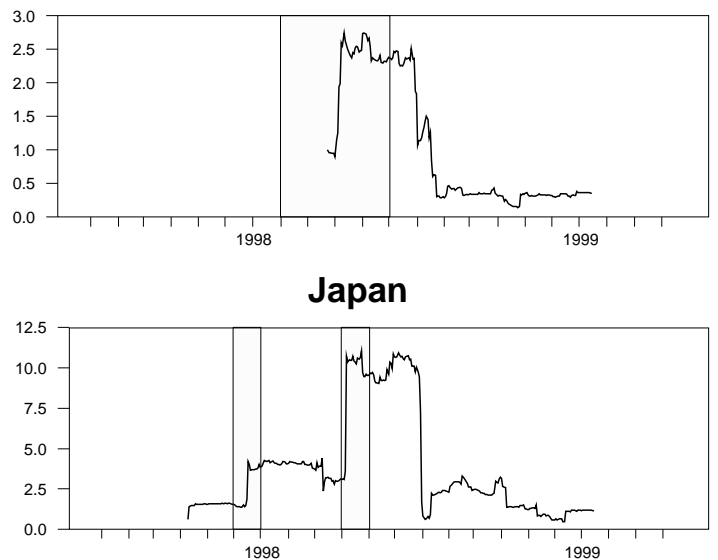

Note: Rolling regressions of exchange rate volatility, defined as squared returns, on a constant and trading volumes (in logarithms) over windows of 60 business days from 1 April 1998 to 1 July 1999. 


\section{References}

Batten and Bhar (1993): "Volume and volatility in yen futures markets: within and across three different exchanges". Macquarie University Working Paper.

Bessembinder, Hendrik (1994): "Bid-ask spreads in the interbank foreign exchange markets". Journal Financial Economics, 35(3), pp. 317-348.

BIS (1997): 67th Annual report.

BIS (1998): International banking and financial market developments. November.

BIS (1999a): "Market liquidity: research findings and selected policy implications". Report for the CGFS.

BIS (1999b): Central bank survey of foreign exchange and derivatives market activity.

Bollerslev, Tim and I Domowitz (1993): "Trading patterns and prices in the interbank foreign exchange market". Journal of Finance, 48, pp. 1421-43.

Bollerslev, Tim and Michael Melvin (1994): "Bid-ask spreads and volatility in the foreign exchange market: an empirical analysis". Journal of International Economics, Vol. 36, pp. 355-372.

Cheung, Yin-Wong and Menzie Chinn (1999):“Traders, market microstructure and exchange rate dynamics". NBER Working Paper 7416, November.

Clark P K (1973): "A subordinated stochastic process model with finite variance for speculative prices”. Econometrica, Vol. 41, pp. 135-155.

Copeland (1976): "A model of asset trading under the assumption of sequential information arrival". Journal of Finance, Vol. 31, pp. 1149-1168.

Copeland (1977): “A probability model of asset trading". Journal of Financial and Quantitative Analysis, Vol. 12, pp. 563-578.

Cornell B (1978): "Determinants of the bid-ask spread on forward foreign exchange contracts under floating exchange rates". Journal of International Business Studies, Vol. 9, pp. 33-41.

Cornell B (1981): "The relationship between volume and price variability in futures markets". The Journal of Futures Markets, Vol. 1, pp. 303-316.

Dumas, Bernard (1996): "Comment on Jorion", in Frankel, Galli and Giovannini The Microstructure of Foreign Exchange Markets. University of Chicago Press, Chicago, pp. 37-40.

Glassman, Debra (1987): "Exchange rate risk and transaction costs: evidence from bid-ask spreads". Journal of International Money and Finance, Vol. 6(4), pp. 479-490.

Goodhart, C and L Figliuoli (1991): "Every minute counts in financial markets". Journal of International Money and Finance, Vol. 10, pp. 23-52.

Goodhart, C, T Ito and R Payne (1996): "One day in June 1993: A study of the working of the Reuters 2000-2 electronic foreign exchange trading system", in Frankel, Galli and Giovannini The Microstructure of Foreign Exchange Markets, University of Chicago Press, Chicago, pp. 107-179.

Grammatikos T and A Saunders (1986): "Futures price variability: a test of maturity and volume effects". Journal of Business, Vol. 59, pp. 319-330.

Harris, L (1986): "Cross-security tests of the mixture of distributions hypothesis". Journal of Financial and Quantitative Analysis, Vol. 21, pp. 39-46.

Hartmann, Philipp (1998a): "Do Reuters spreads reflect currencies' differences in global trading activity" in Currency Composition and Foreign Exchange Markets. Cambridge University Press, pp. 132-162. 
Hartmann, Philipp (1998b): "Trading volumes and transaction costs: from the short run to the long run" in Currency Composition and Foreign Exchange Markets. Cambridge University Press.

Hartmann, Philipp (1999): "Trading volumes and transaction costs in the foreign exchange market". Journal of Banking and Finance, Vol. 23, pp. 801-824.

Jorion, Philippe (1996): "Risk and turnover in the foreign exchange market", in Frankel, Galli and Giovannini The Microstructure of Foreign Exchange Markets, University of Chicago Press, Chicago, pp. 19-36.

Karpoff, Jonathan (1987): “The relation between price changes and trading volume: a survey". Journal of Financial and Quantitative Analysis, Vol. 22(1), pp. 109-126.

Lyons, Richard (1995): "Test of microstructural hypotheses in the foreign exchange market". Journal of Financial Economics, Vol. 39, pp. 321-351.

Lyons, Richard (2000): The microstructure approach to exchange rates. MIT Press, forthcoming.

Melvin, Michael and Xixi Yin (2000): "Public information arrival, exchange rate volatility and quote frequency". The Economic Journal.

Richardson, G, S E Sefcik and R Thomson (1987): "A test of dividend irrelevance using volume reaction to a change in dividend policy". Journal of Financial Economics, Vol. 17, pp. 313-333.

Shang-Jin, Wei (1994): “Anticipations of foreign exchange volatility and bid-ask spreads". NBER Working Paper No. 4737.

Tauchen, G and M Pitts (1983): "The price-variability volume relationship on speculative markets". Econometrica, Vol. 51 (March), pp. 485-505. 



\section{Recent BIS Working Papers}

No Title Author

77

October 1999

78

October 1999

79

November 1999

80

November 1999

81

November 1999

82

November 1999

83

January 2000

84

January 2000

85

January 2000

86

March 2000

87

May 2000

88

June 2000

89

August 2000

90

September 2000

91

October 2000

92

October 2000
Perceived central bank intervention and market expectations: an empirical study of the yen/dollar exchange rate, 1993-96

Banking and commerce: a liquidity approach

Pass-through of exchange rates and import prices to domestic inflation in some industrialised economies

A note on alternative measures of real bond rates

Interbank interest rates and the risk premium

Sacrifice ratios and the conduct of monetary policy in conditions of low inflation

Switching from single to multiple bank lending relationships: determinants and implications

What have we learned from recent financial crises and policy responses?

A defence of the expectations theory as a model of US long-term interest rates

Information, liquidity and risk in the international interbank market: implicit guarantees and private credit market failure

Monetary policy in an estimated optimisation-based model with sticky prices and wages

Evidence on the response of US banks to changes in capital requirements

Forecast-based monetary policy

Bank capital regulation in contemporary banking theory: a review of the literature

Measuring potential vulnerabilities in emerging market economies

Recent initiatives to improve the regulation and supervision of private capital flows
Gabriele Galati and

William Melick

Joseph G Haubrich and João A C Santos

Jonathan McCarthy

Palle S Andersen

Henri Pagès

Palle S Andersen and William L Wascher

Luísa A Farinha and João A C Santos

William R White

Gregory D Sutton

Henri Bernard and

Joseph Bisignano

Jeffery D Amato and Thomas Laubach

Craig Furfine

Jeffery D Amato and Thomas Laubach

João A C Santos

John Hawkins and Marc Klau

William R White 


ISSN 1020-0959 